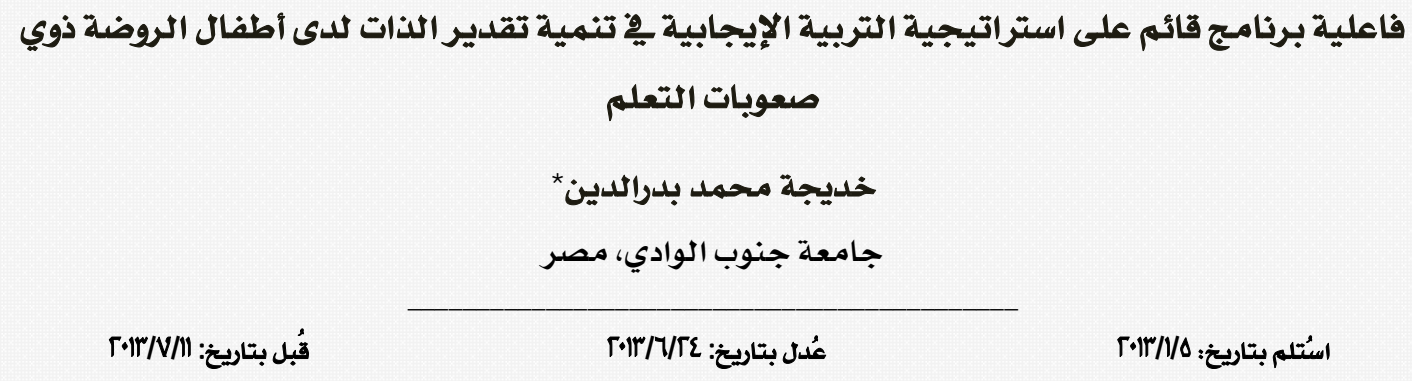

أشارت نتائج العديد من الدراسات أن الأطفال ذوي صعوبات التعلم يعانون من تدني يٌّ تقدير الذات مقارنة بالأطفال العاديين، مما قد يؤثر

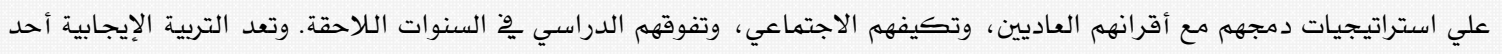

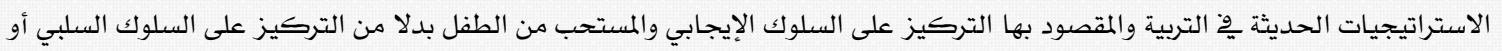

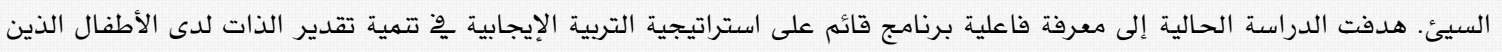

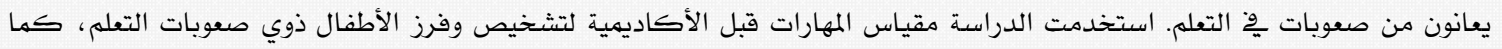

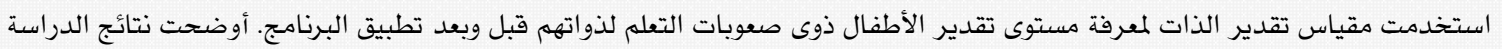

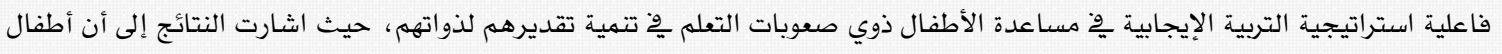

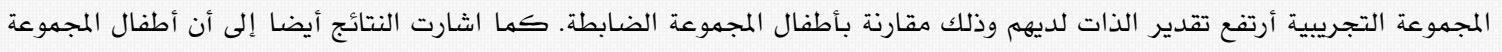

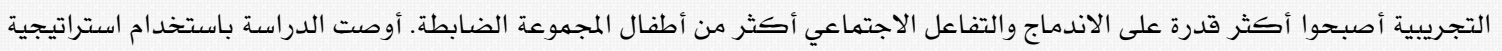

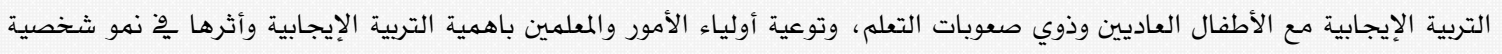

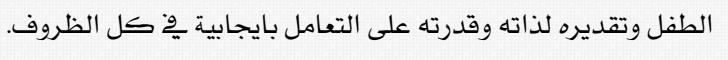
الكلمات المفتاحية : التربية الإيجابية ، تقدير الذات، طفل الروضة، صعوبات التعلم.

\title{
The Effectiveness of a Program Based on the Strategy of Positive Education in the D evelopment of Self-Esteem of Kindergarten Children with Learning Difficulties
}

Khadega M. Badraldien*

South Valley University, Egypt

The results of several studies have shown that children with learning difficulties suffer from low selfesteem compared to normal children, which may affect their integration with their normal peers, social adaptation, and their academic superiority in subsequent years. Positive education is one of the modern strategies in education which is intended to focus on the positiveand desirable behavior of the child rather than focusing on the negative or bad behavior. The present study aimed to find out the effectiveness of a program based on the strategy of positive educationin the development of self-esteem for children who suffer from learning difficulties. The study used the pre-academic skills scale to diagnose and sort children with learning difficulties and the self-esteem scal e to determine the level of appreciation for children with learning difficulties for themselves before and after theimplementation of the program. Overall, the results of thestudy indicated that the positive education program hel ped in developing children's self-esteem and appreciation for themselves. The results showed that children of the experimental group had better selfesteem than the control group, and the positive education program had a significant impact on the development of self-confidence and self image. The results also indicated that the experimental group was better in integration and social interaction than the control group. The study recommended using the strategy of positive education not only with normal children but also with those with learning difficulties. The study also recommended that parents' and teachers' awareness of the importance of positive education and its impact on the growth of the child's personality and abilities should be enhanced.

Keywords: positive education, self-esteem, early childhood, learning disabilities.

*leeds0@hotmail.com 
القصـور ومحاولة علاجها وعدم الاهتمام بما لديه

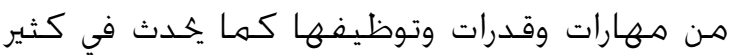

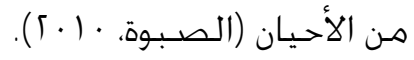

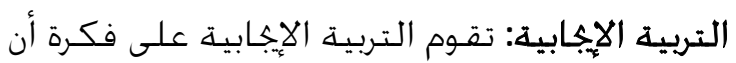

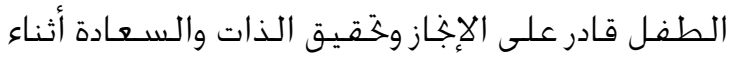

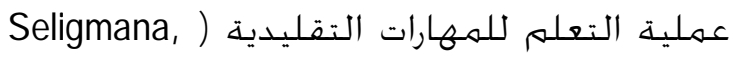
(Ernstb, Gillhamc, Reivicha \& Linkinsd, 2009

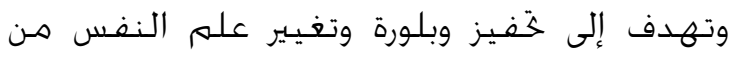

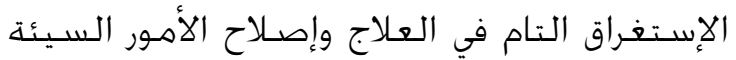

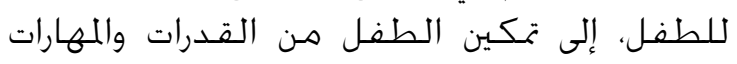

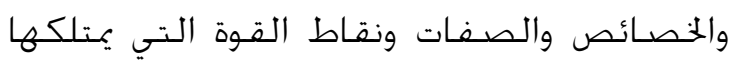

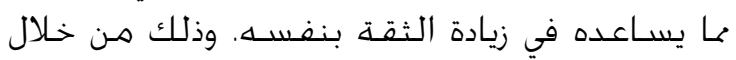

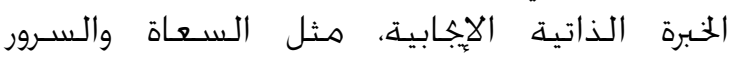

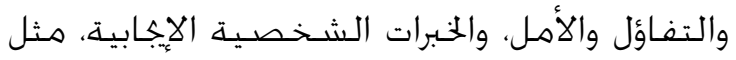

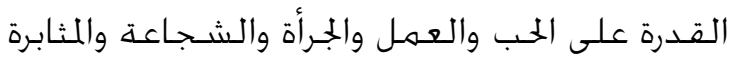

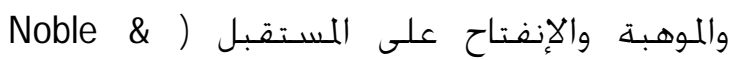

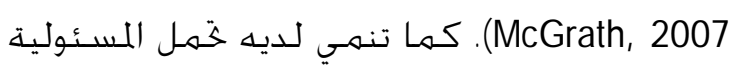

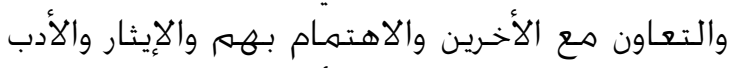

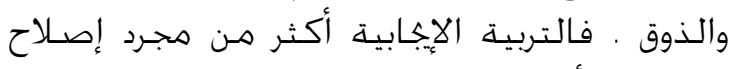

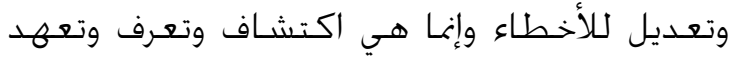

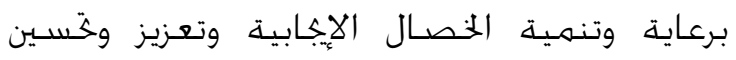

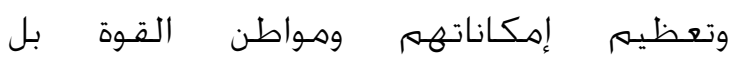

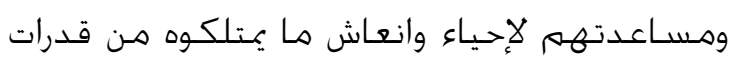

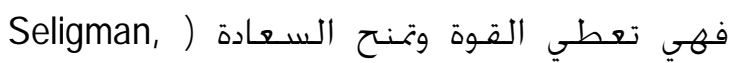

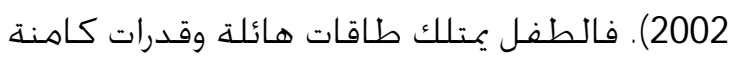

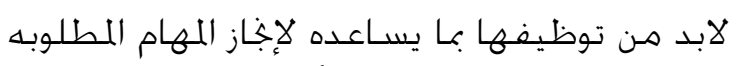

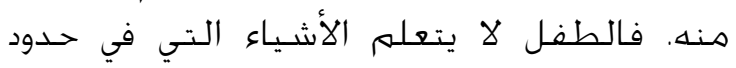

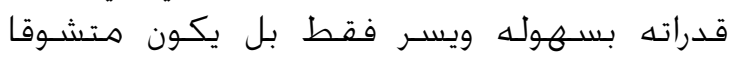

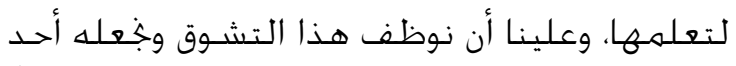
نقاط القوة التي تسـاعده على تكوين مفهوماً

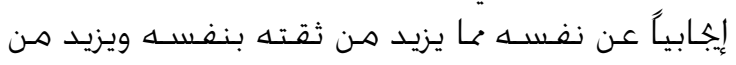

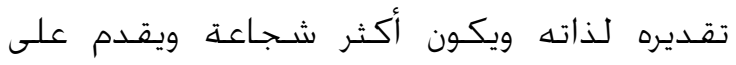

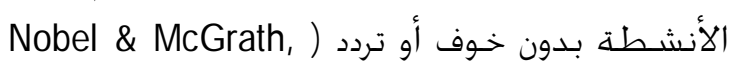

(2008

ويشير أبومعال (1997 () إلى أن اللفـاهيم تتكون نتيجة

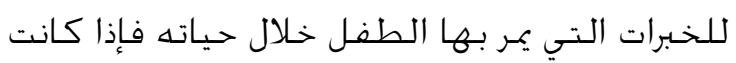

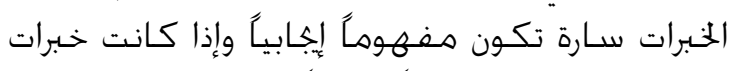

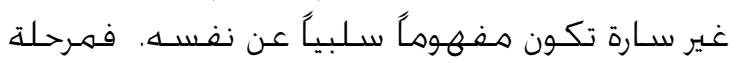

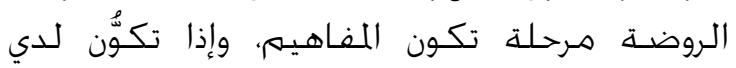

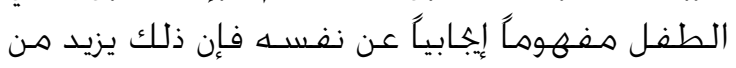

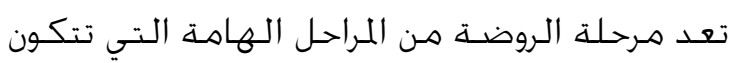

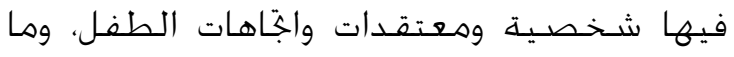

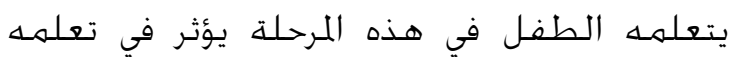

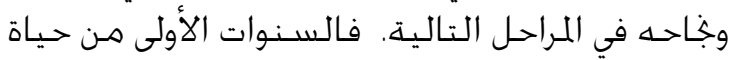

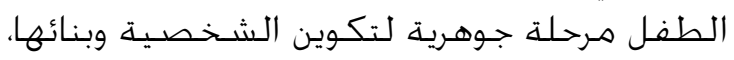

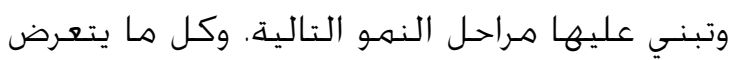

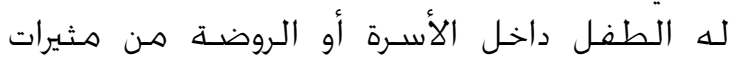
عقلية واجتماعية ولغوية وحسية لكها لها أثار إيجابية

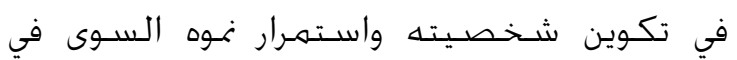

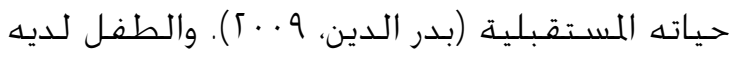

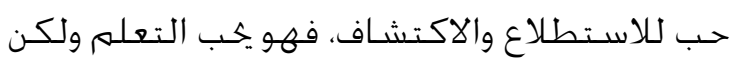

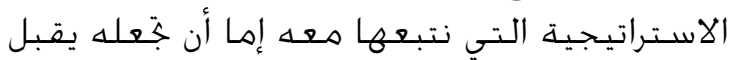

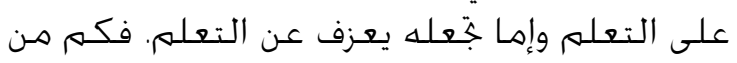

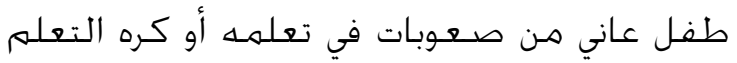

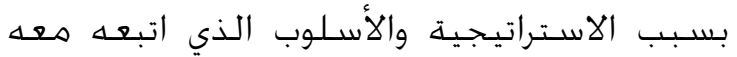

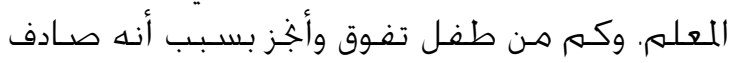

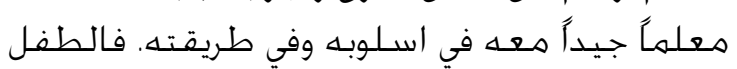

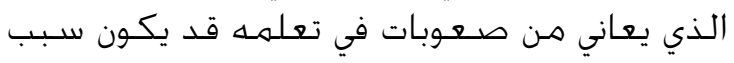

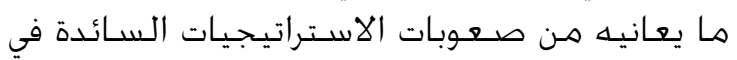

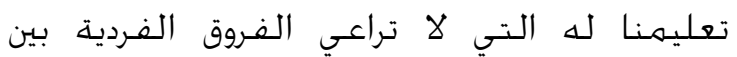
الأطفال.

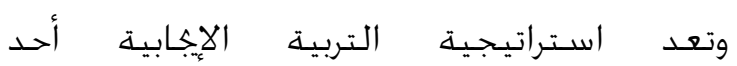

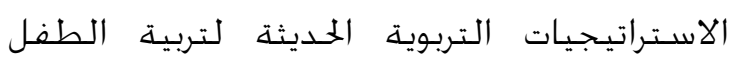

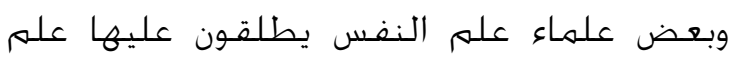

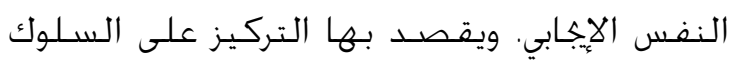

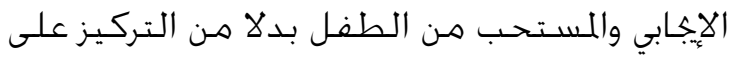

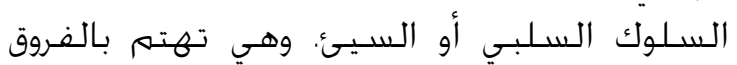

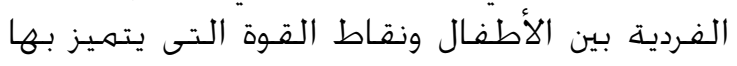

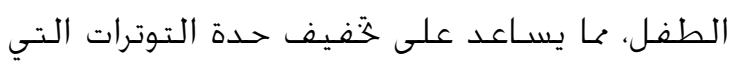

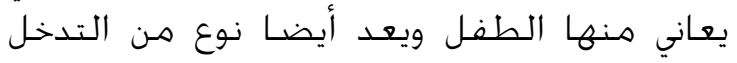

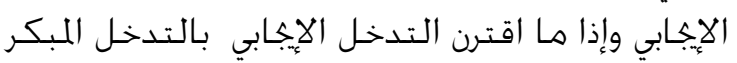

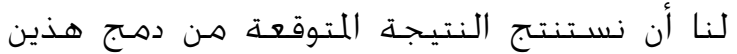

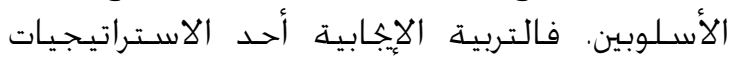

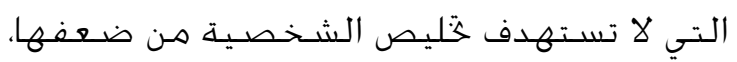

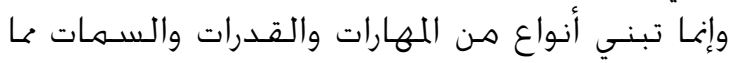

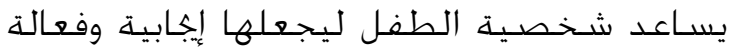

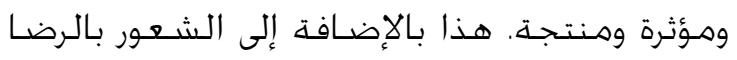

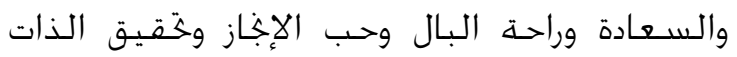

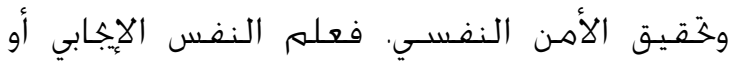

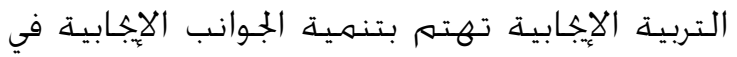

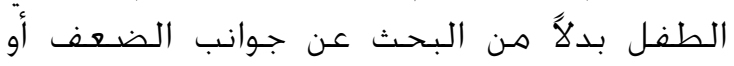


ذوي صعهوبات التعلم يسـاعد في خفض الصــوبات

$$
\text { التي يعانون منها. }
$$

وهناك عدة أسس للتربية الإيجابية تتمثل في احترام

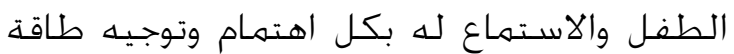

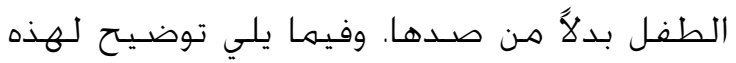

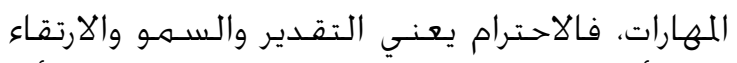

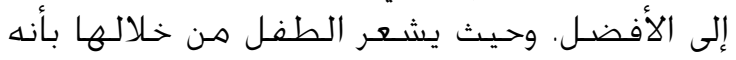

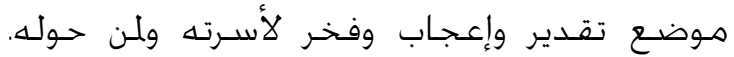

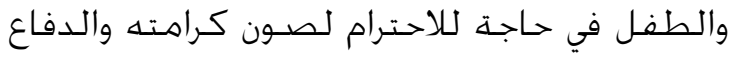

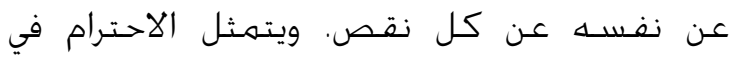

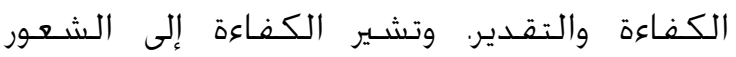

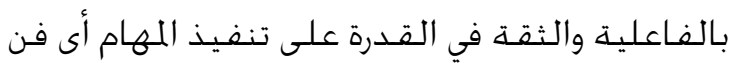

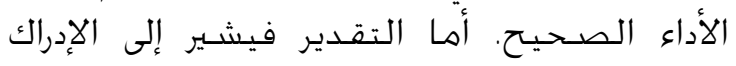

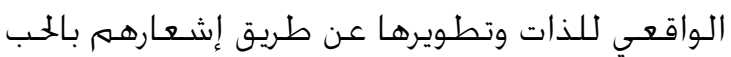

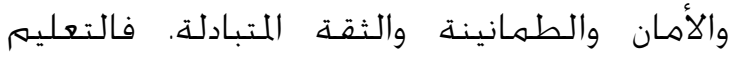

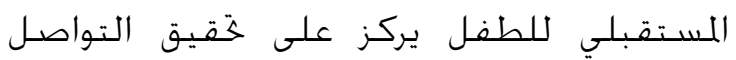

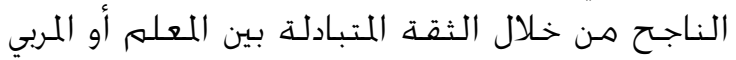

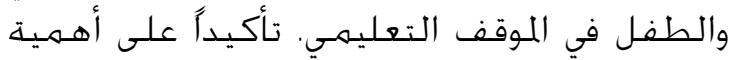

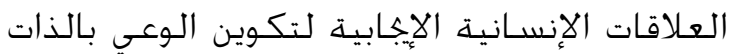

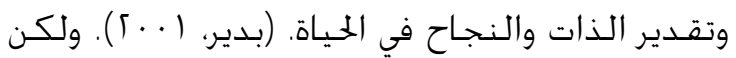

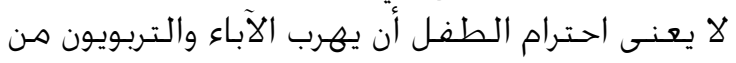

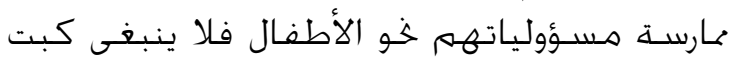

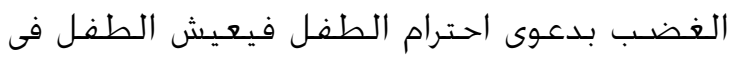

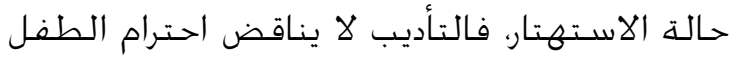

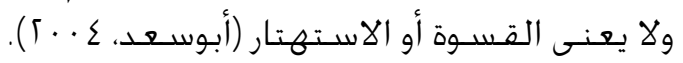

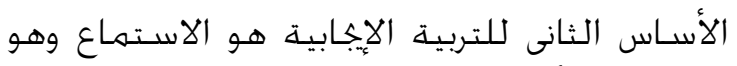

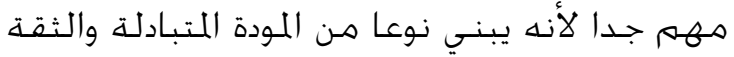

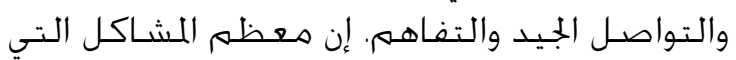

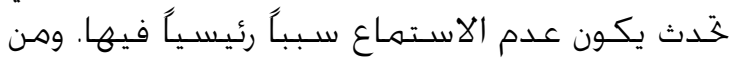

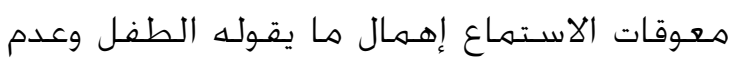

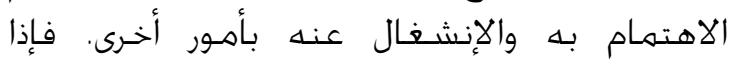

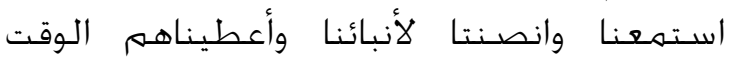
الكافي لعرفنا كيف يفكرون وماذا يريدون (أبوسعد.

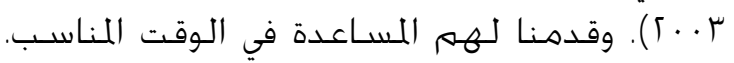

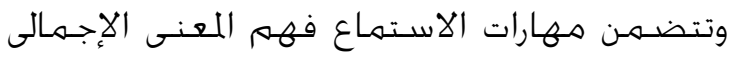

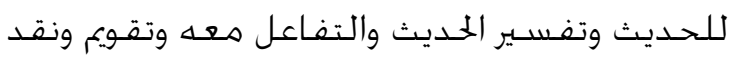

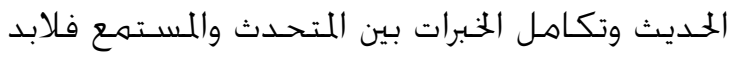

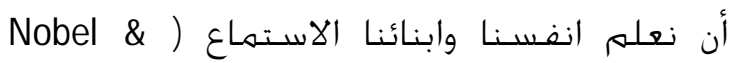

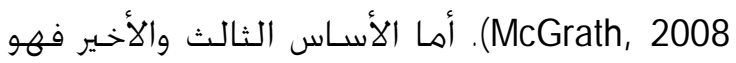

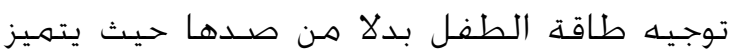

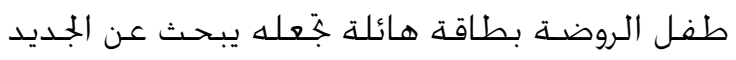

ثقته بنفسـه وتقديره لذاته ويزيد هن قدرته على

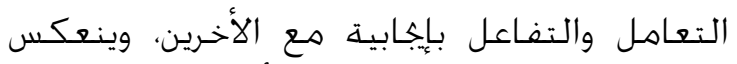

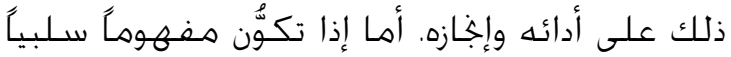

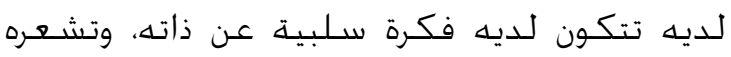

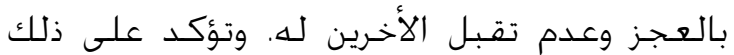

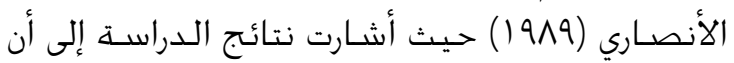

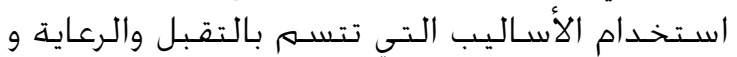
الإثابة يساعد على رفع تقدير الذات لديهمه.

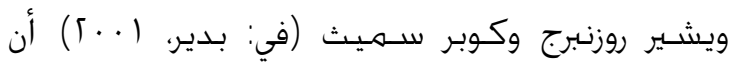

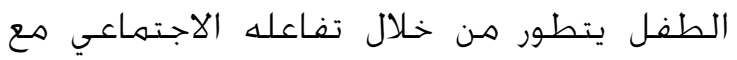

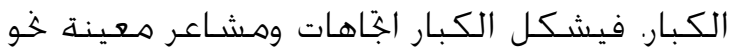

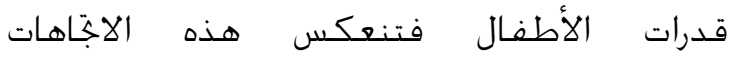

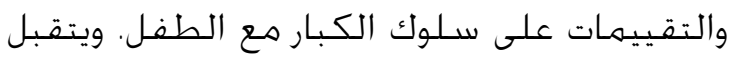

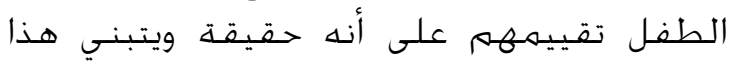
التقييم وتتكون فكرته خو ذاته. فإذا كان الكبار

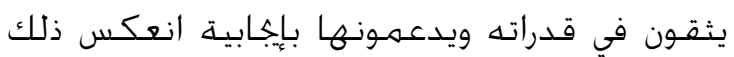
عليه، وإذا استهان به الكبار استهان بنفسـه ولا لـانهان

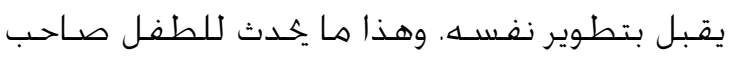

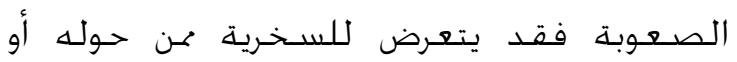

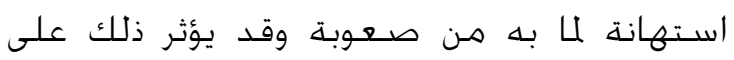

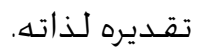

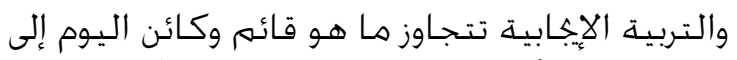

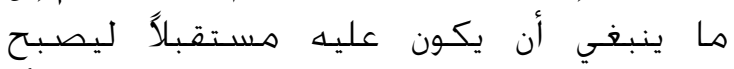

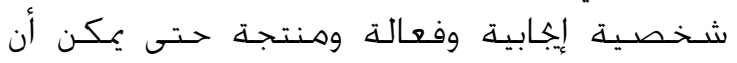
(Criss, Pettit, يرضى عن نفسـه ويعيش سعيدار) Bates, Dodge \& Lapp, 2002)

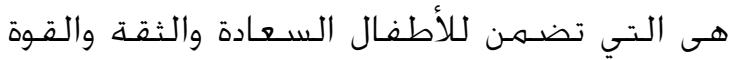

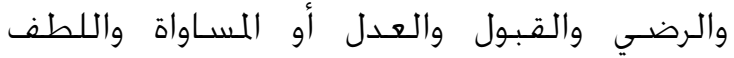

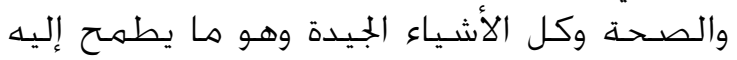

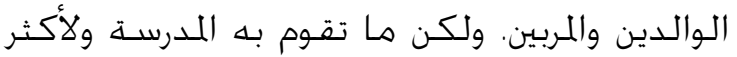

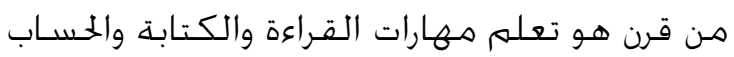

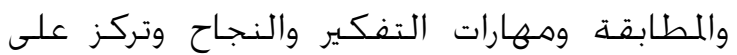

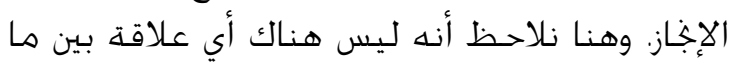

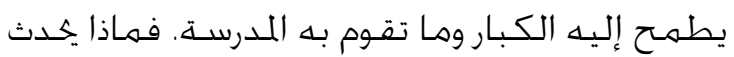

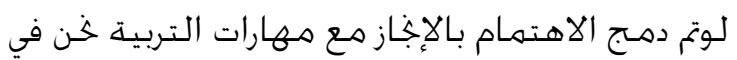

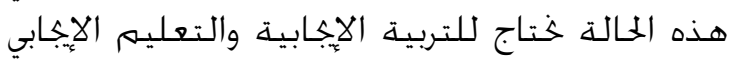
(Martin, Randal, Jane, Karen \& Mark, 2009) فالتربية الإبحابية تساعد الطفل على الإقبال

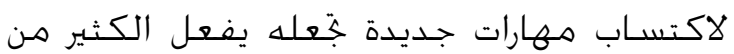

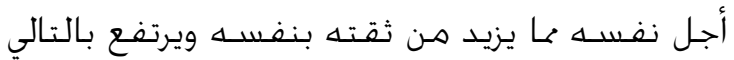

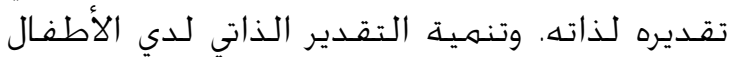


تقدير الذات: ذات الطفل هي جوهر شخصيته بكل ما تشتمل عليه من معتقدات دات وقيهم وهشاعر واجتاهات يكتسبها الطفل ويدركها نتيجة تفاعله تفاعله

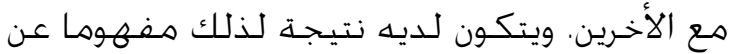

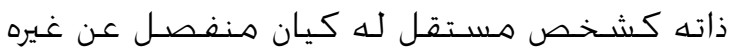

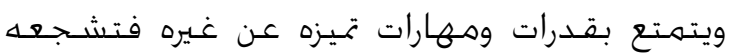

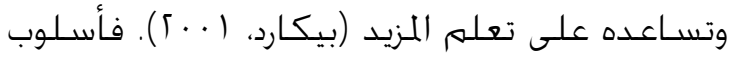

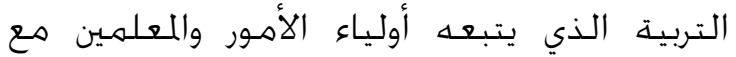

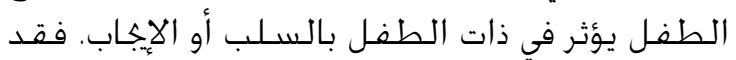

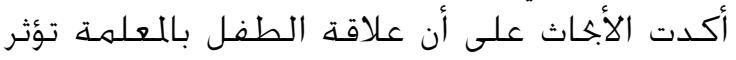

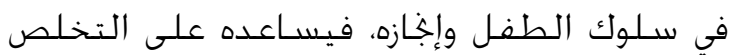

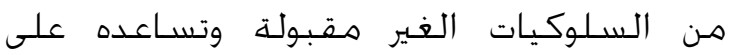

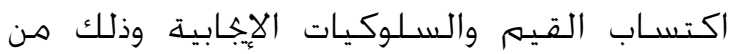

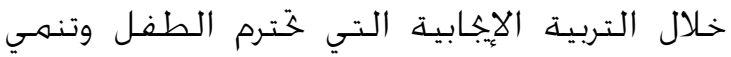

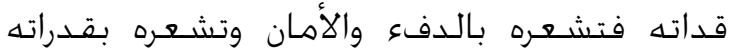

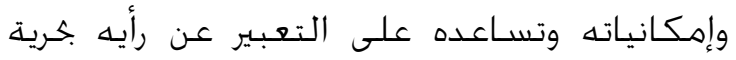

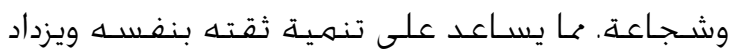

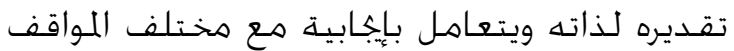

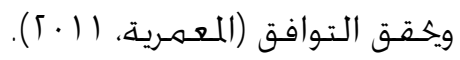

ويرى محهد (1991) أن الذات هي أسـاس التوافق

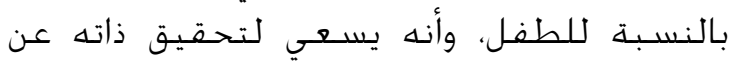

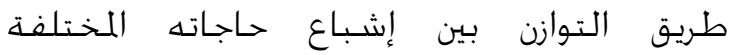

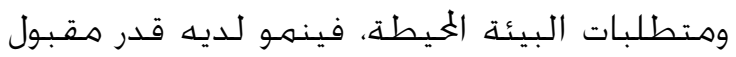

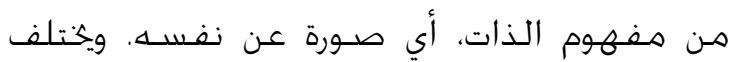

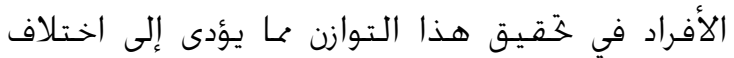

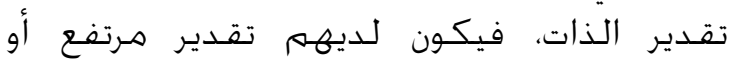

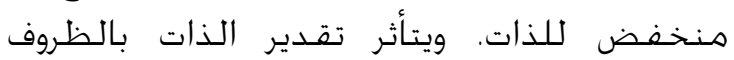
البيئية الغيطة، فإذا كانت مثيرات البيئة إيمابية

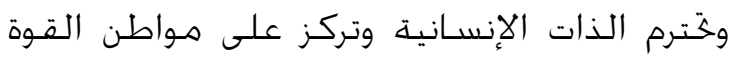

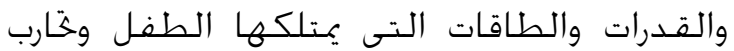
الإحباط فيتمتع الطفل بتقدير مرتفع للذات أمات أما إذا

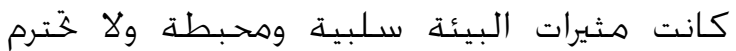

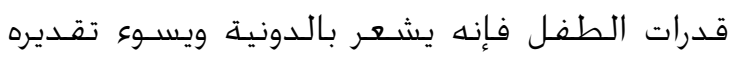

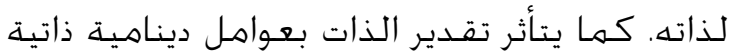

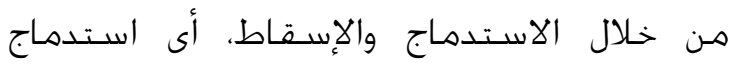

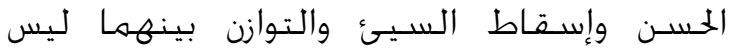

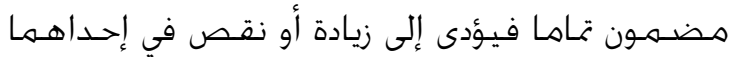

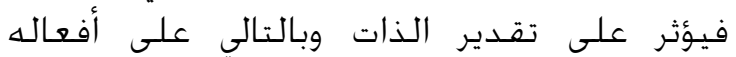
وسلوكه. فئر

ويشـير سليمان (1991) إلى أن تقـدير الذات هو نظـرة

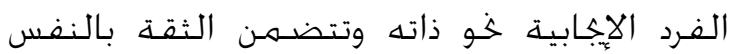

ويكتشـف ما حوله، وهذا ما يبعله في تطور مسـتمر لقدراته ومهاراته (بهادر،

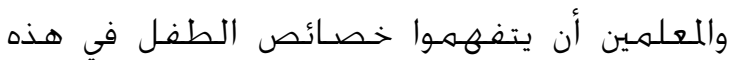

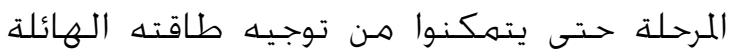

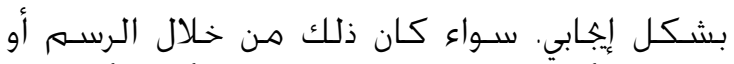

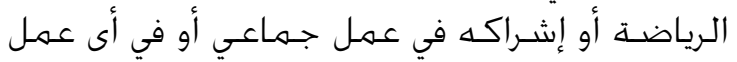

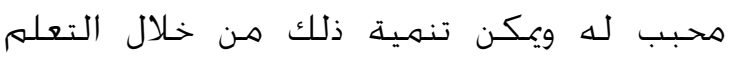

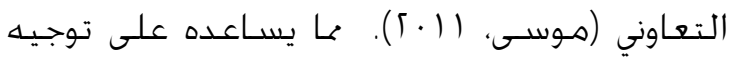

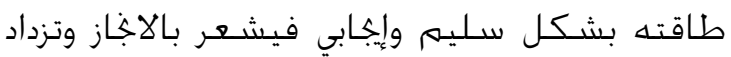
ثقتـه بنفسـه ويرتفع تقديره لذاته.

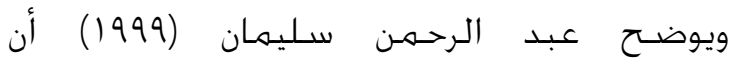

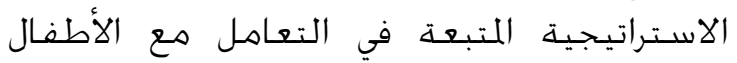

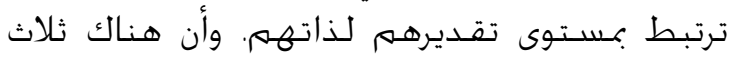

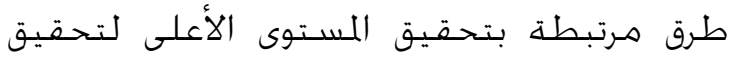

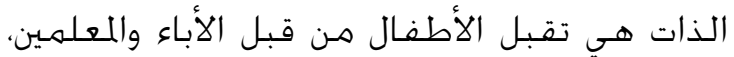

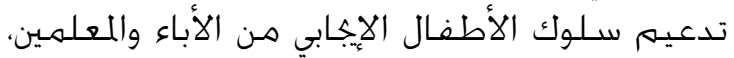

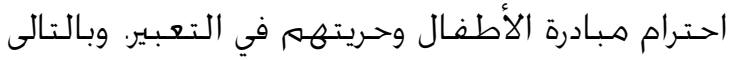

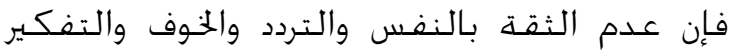

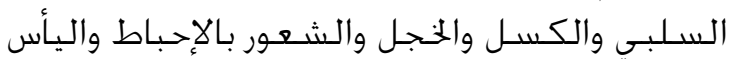
والإعتمادية ومصـاحبة السـلبيين من معوقات الإحسات

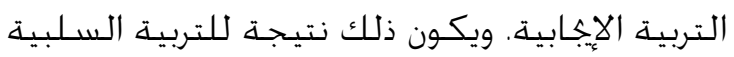

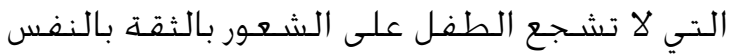

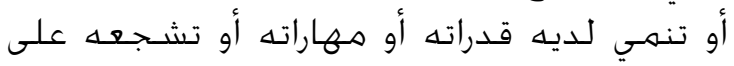

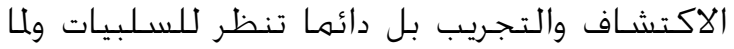

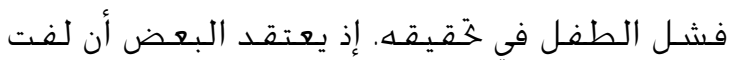

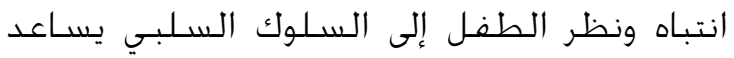

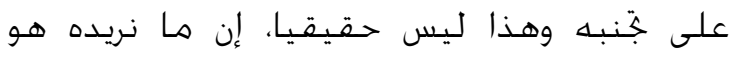

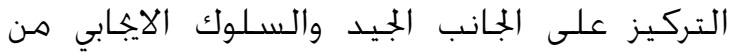

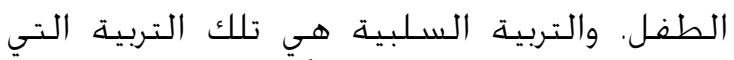

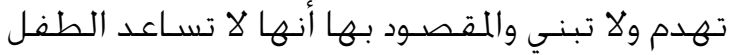

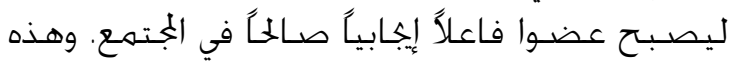

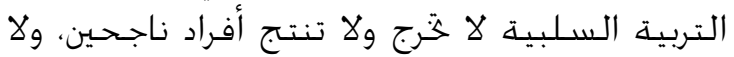

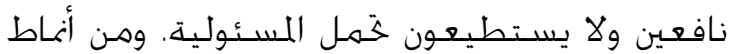

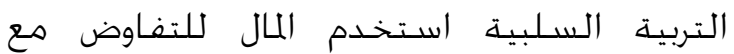

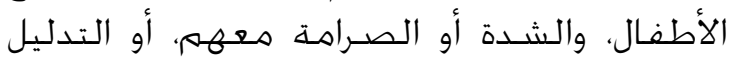

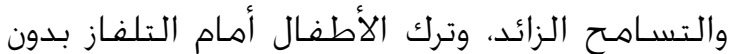

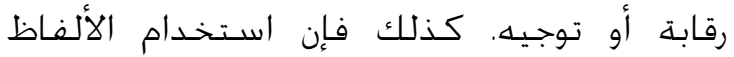

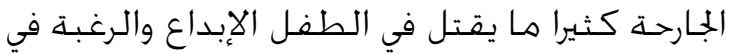

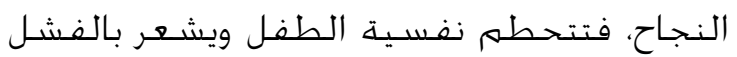

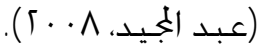




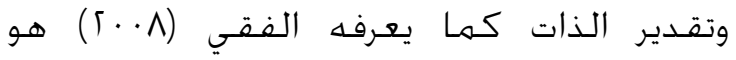

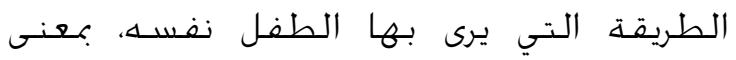

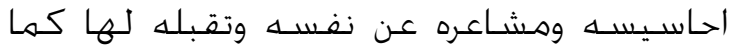

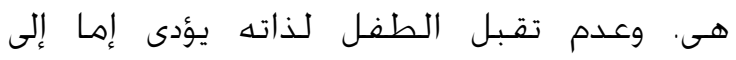

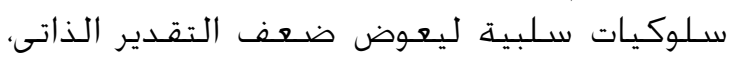

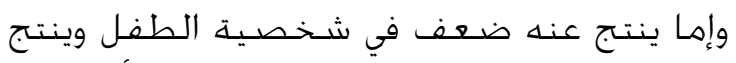

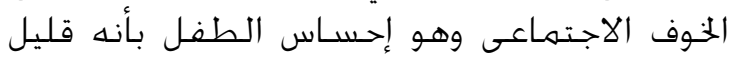

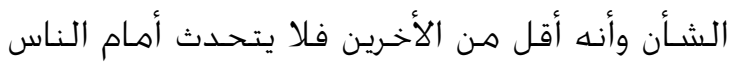

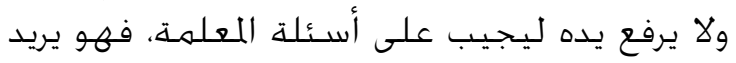

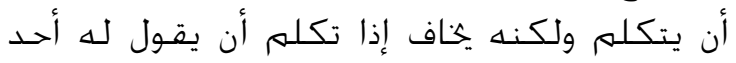

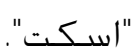

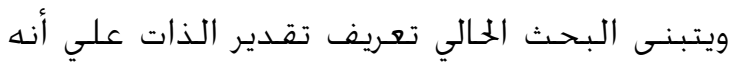

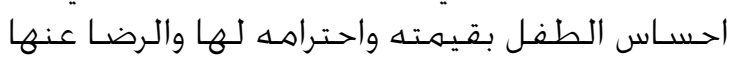

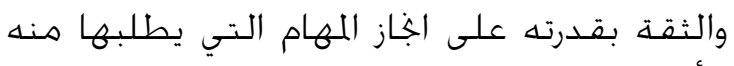

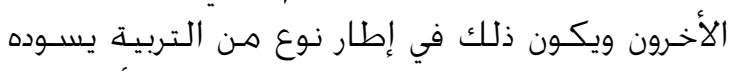

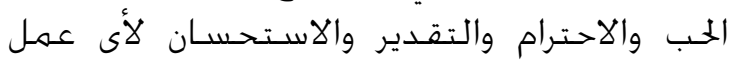

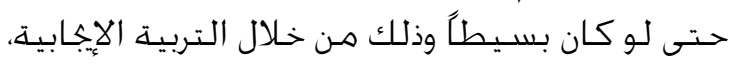

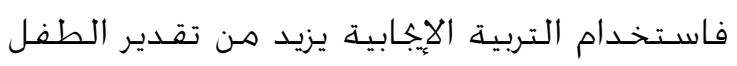

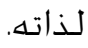

وهناك عدة أنواع لتقدير الذات، فقـد أشـار علي

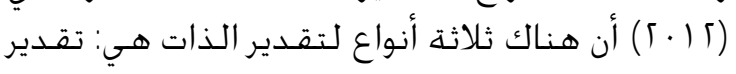

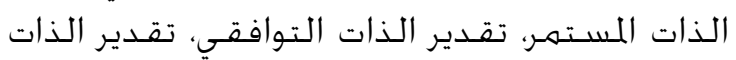

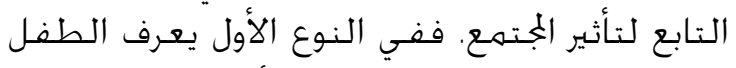

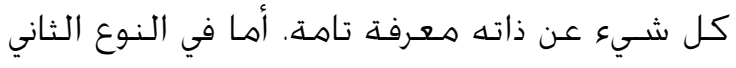

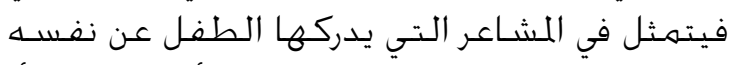

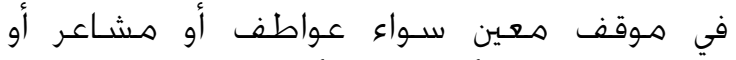

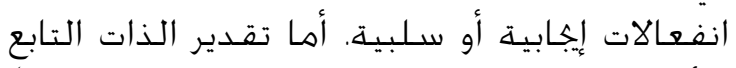

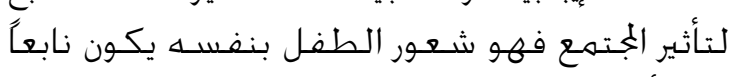

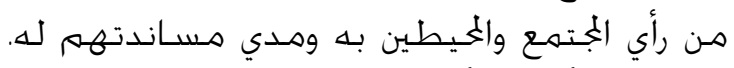

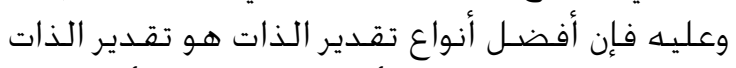

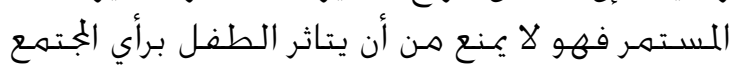
ويتأثر بالمواقف التي يمر بها.

وهناك عدة عوامل تؤثر في تقدير الذات، فقـد أشـار

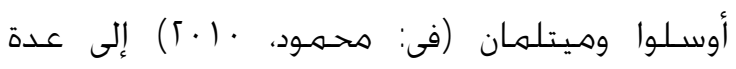

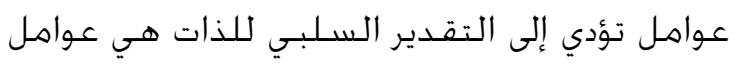

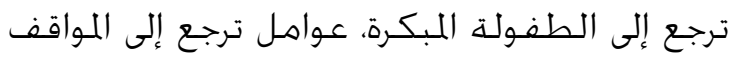

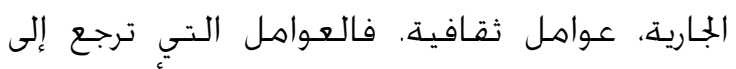

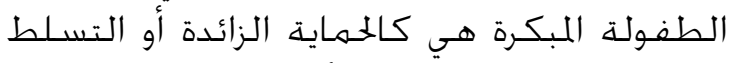

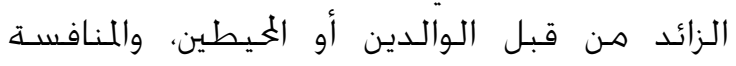

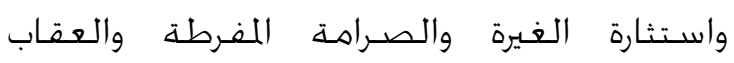
والتخـويف وكلها من الأسـاليب الخاطئة والسـلبية والهية
بدرجة معقولة وكافية وإحسـاس الطفل بكفائته

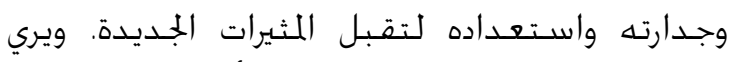

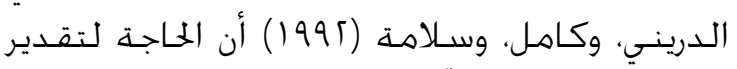

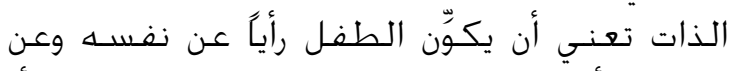

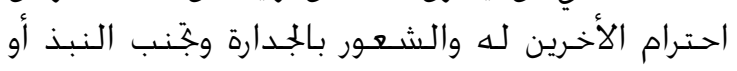

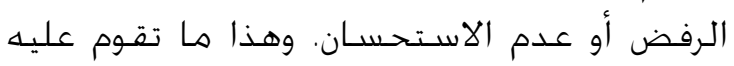

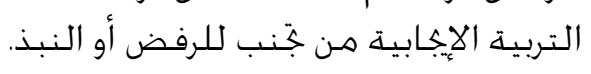
ويعرف محهمد (1991) تقدير الذات بأنه اجناهات

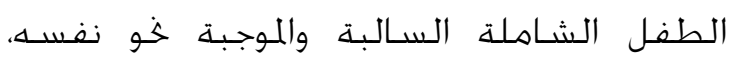
والأطفال ذوو التقدير المرتفع للذات يتميزون بأنهمه

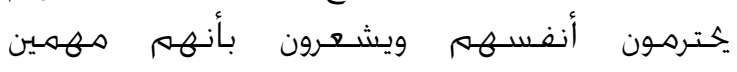

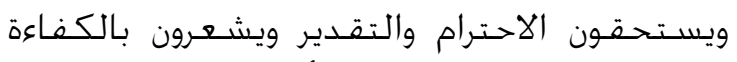

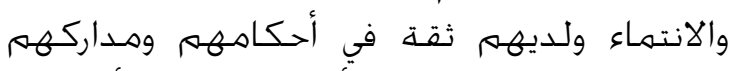

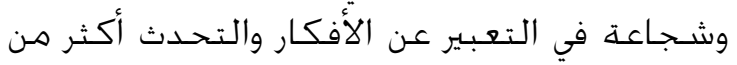

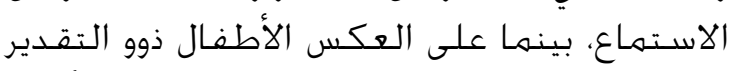

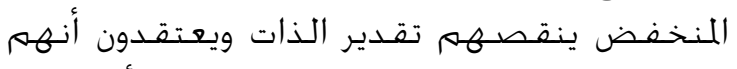

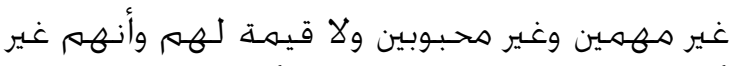

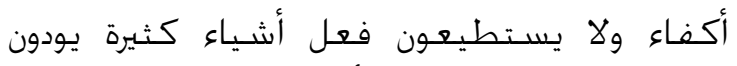

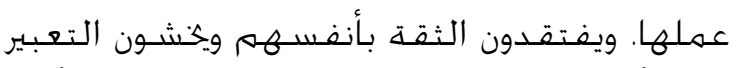

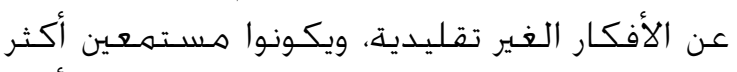

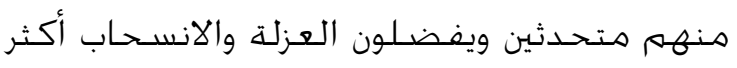

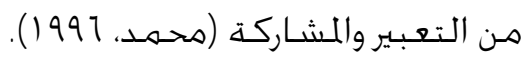

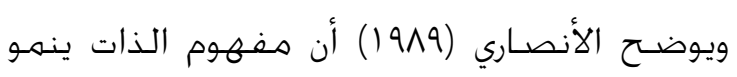

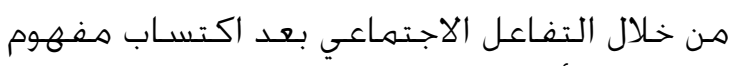

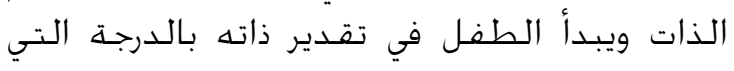

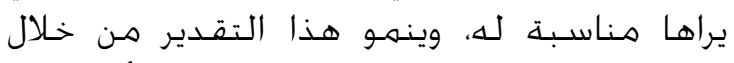

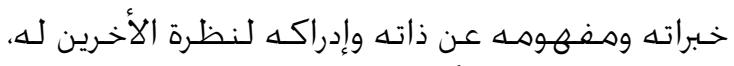

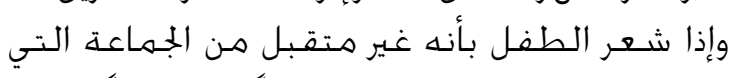

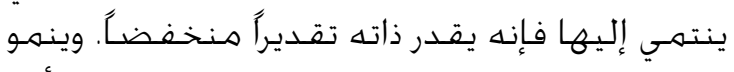

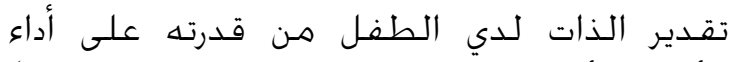

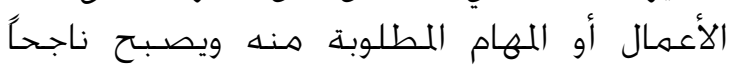

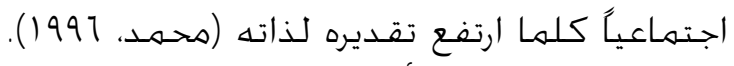

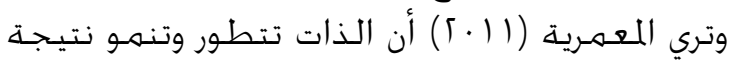

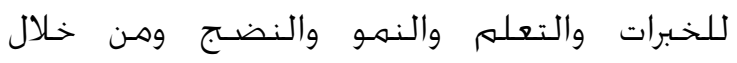

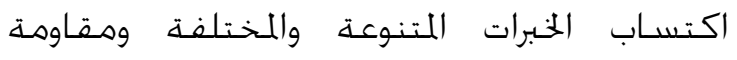

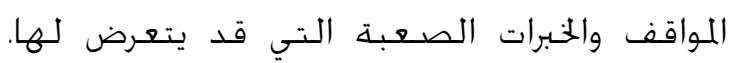

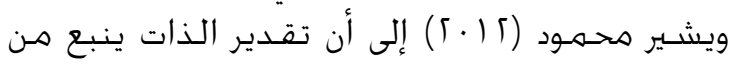

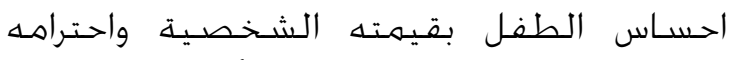

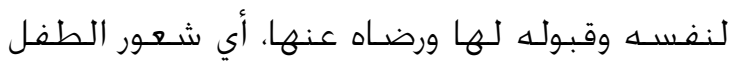

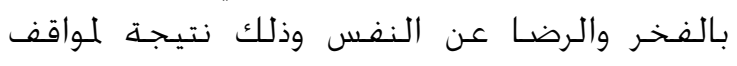
النجاح التي يمر بها. 
التفكير، التذكر، اضطرابات اللغة الشفهية. وأى أى

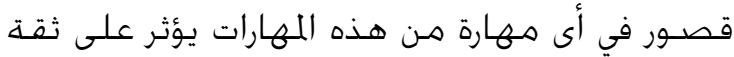

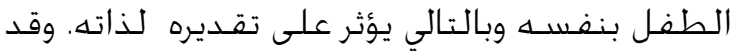

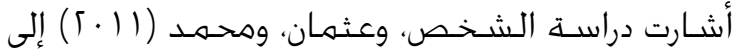

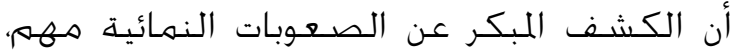
لأنه يساعد في تقديم المساعدة والإجراءات الوقائية الماتية

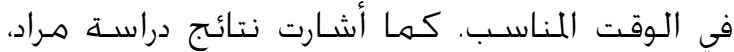

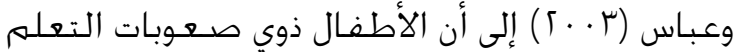

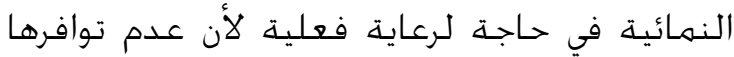

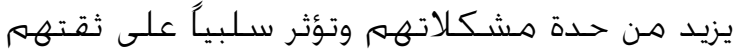
بأنفسهم وتنخفض طدة طموحاتهم وتقل دافعيتهم ويقل تقديرهم لذواتهم.

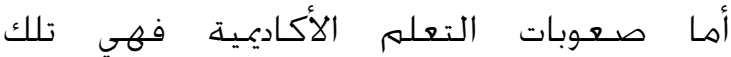

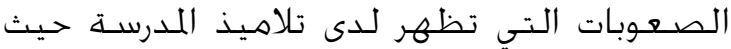

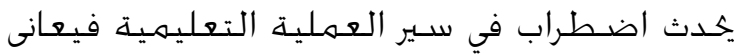

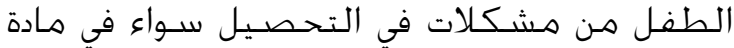

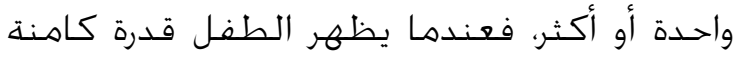

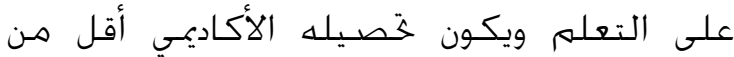

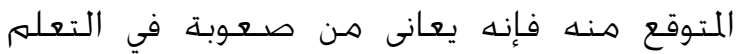

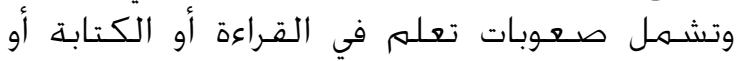

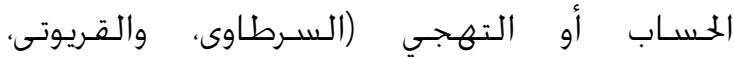

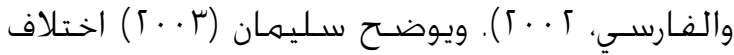

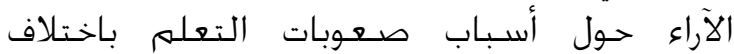

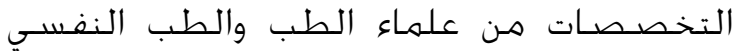

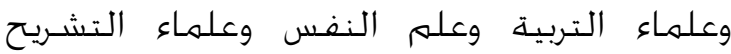

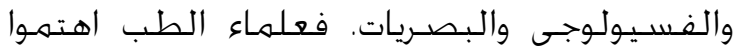

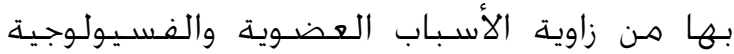

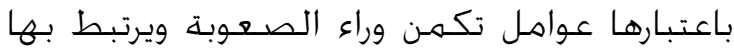

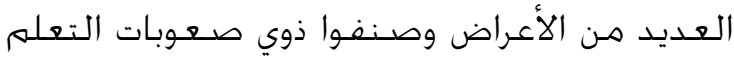

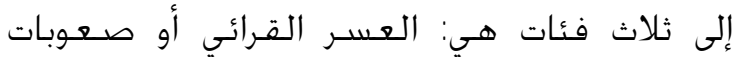

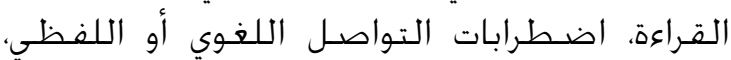
مشكلات التكامل البصري الحمركي.

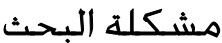

أشارت الدراسات التي أجريت على الأطفال ذوي

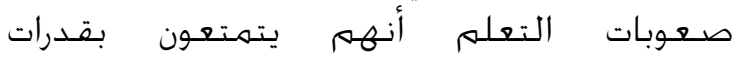

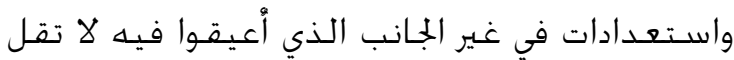

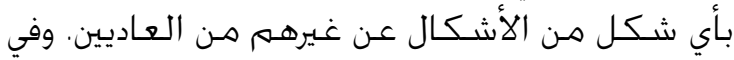

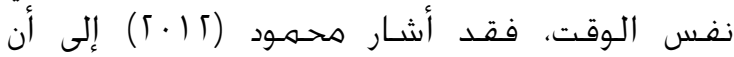

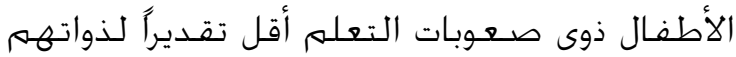

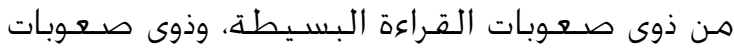

في التربية ولا تقوم على التربية الإيجابية. أما عوامل

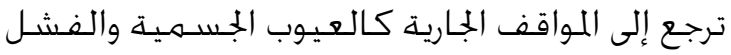

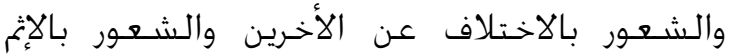

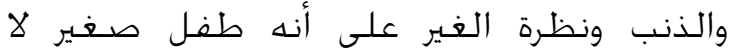
يستطيع القيام بالمهام اللطلوبة منه. أما العواهل

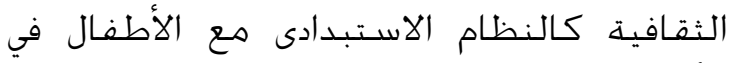

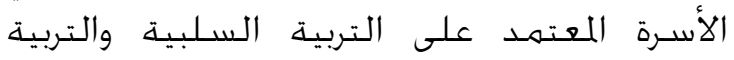
الاسـتبـداديـة في المـدرسـة.

\section{صعوبات التعله}

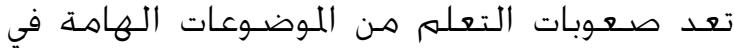

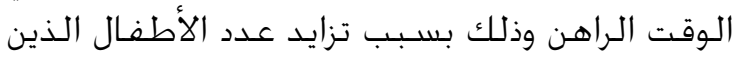

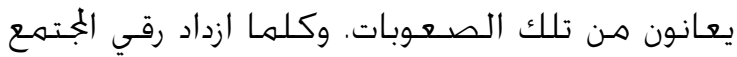

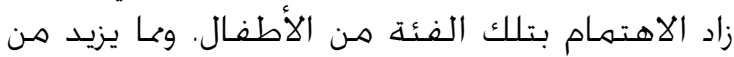

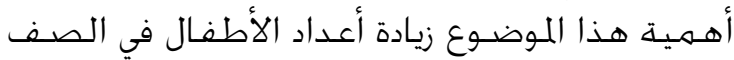

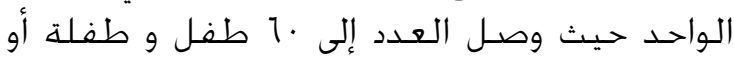

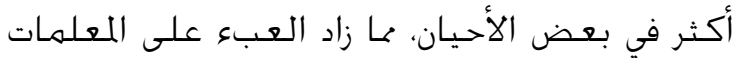

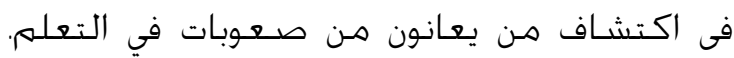

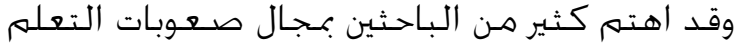

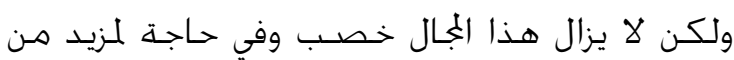

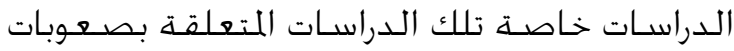

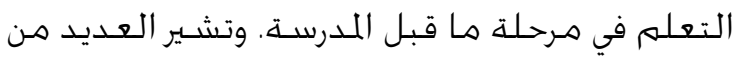

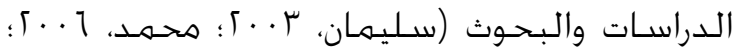

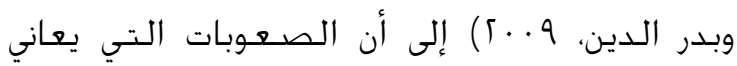

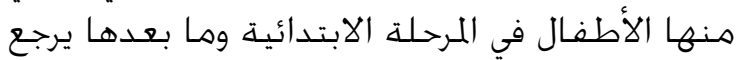

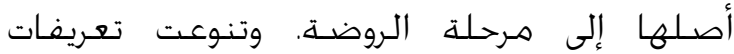

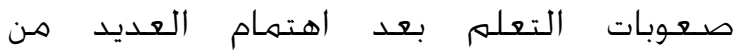
المتخصين في مختلف التخصصات كالطب النبات النفسي والفسيولوجي والأعصـاب والنطق والكلام.

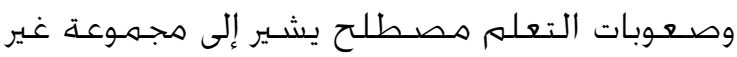

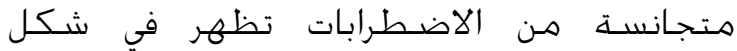

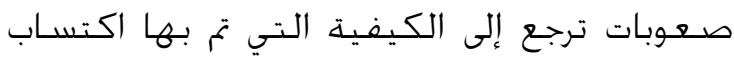

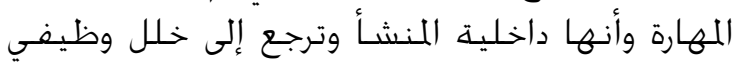

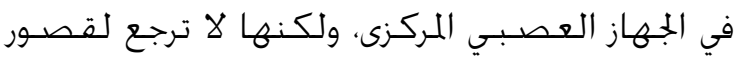

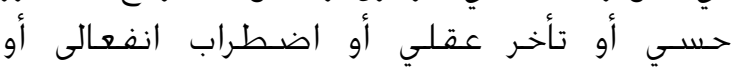

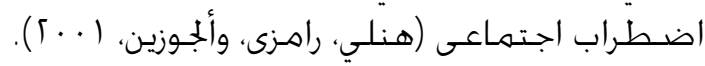

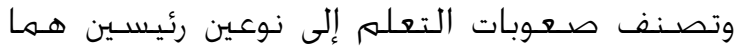

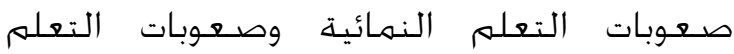
الأكاديمية. فصعوبات التعلم النمائية هي تلك الك التهات الصعوبات التى غالبا ما خحدث لأطفال ما قبا قبل المدرستة وهي صعوبات تتعلق بالانتباه والإدراك. 
قدرات وههارات للتغلب على صعوبات التعلم من

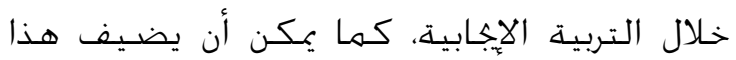

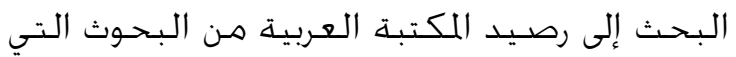

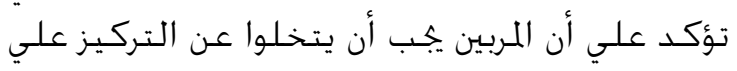

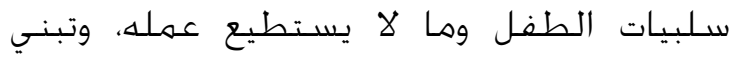

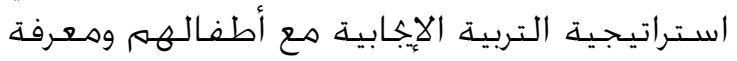

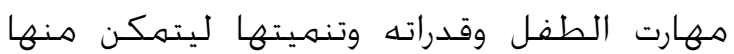

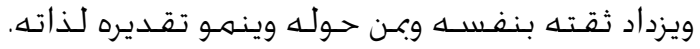

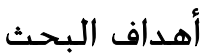

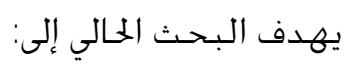

1 - التحقق ما إذا كان الأطفال ذوي صعوبات

التعلم لديهم تدني في تقدير الذات مقارنة

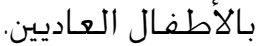
أ - إعداد برناهـج قائم على اسـتراتيجية التربية

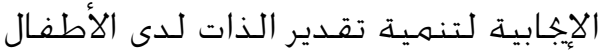

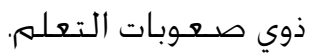
r - التعرف علي أثر البرنامج المقترح في تنعمية التهات

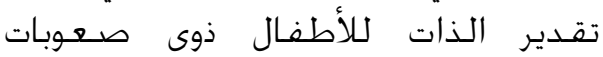

$$
\text { التعلهم }
$$

ع - إلقـاء هـيد مـن الضـوء على اثر استخـدام

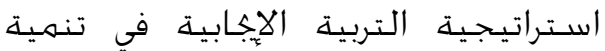

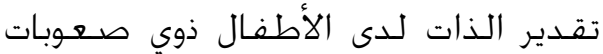
التعلهم

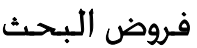

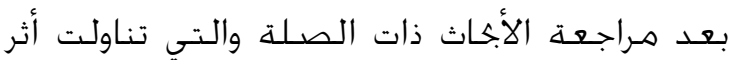

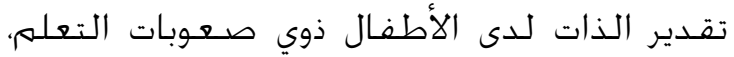
وكذلك الأثر الإيجابي لإسـتراتيجية التربية الإيجابية،

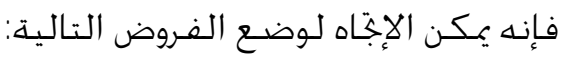

' ل توجد فروق ذات دلالة احصائية علي مقياس تقدير الذات بين متوسطات دات الات درجات الأطفال العاديين ومتوسطات لهنات درجات الأطفال ذوي صعوبات التعلم الإلم العات

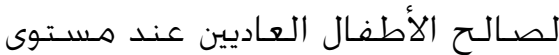

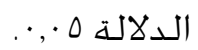

r. توجد فروق ذات دلالة احصائية بين

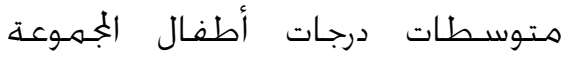

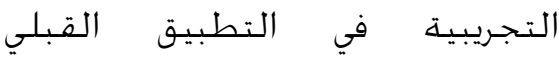
ومتوسـطات درجاتهم في فئهي التطبيق

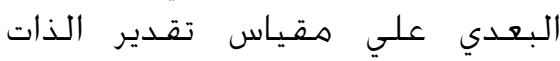

القراءة البسـيطة أقل تقديراً لذواتهمه من الأطفال

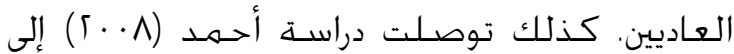

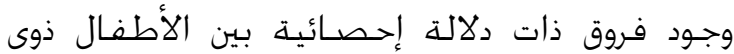

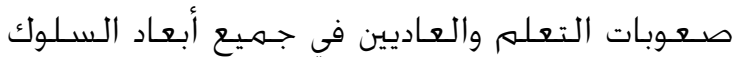

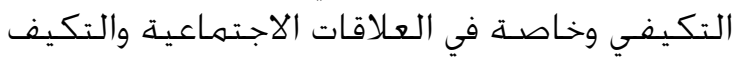

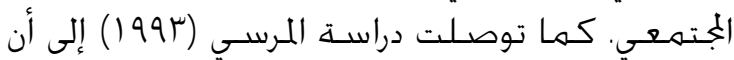

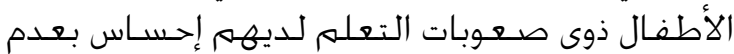

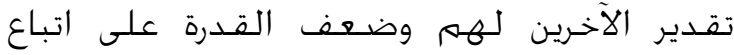
التعليمات التي تطلب منهمه لهنه

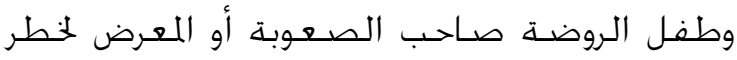

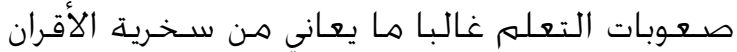

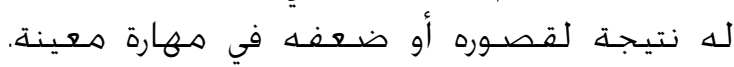
ونتيجة لتكرار الميطين بالطفل بأنه لا يعرف أو لا لأل

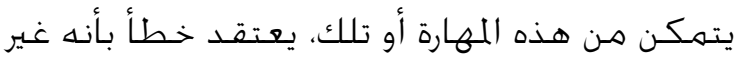

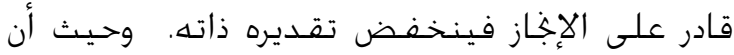
مفهوم الطفل عن ذاته وما يعتقده الأخرون عندانه

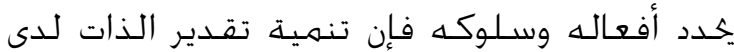

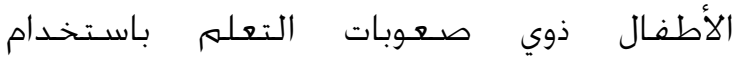

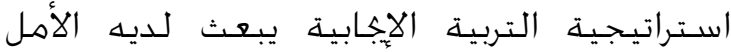

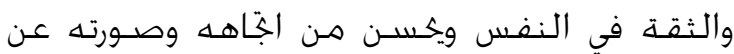

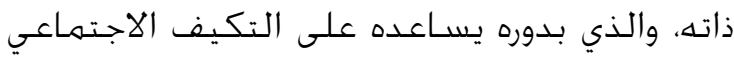

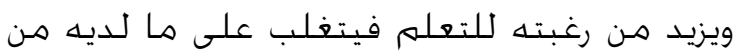
صعوبات وهشكلات في المستقبل. وبالتالي فإنه هاليه يمكن خديد مشكلة البحتث في السؤالين التاليـين: ا. هل يعاني الأطفال ذوي صعهوبات التعلم

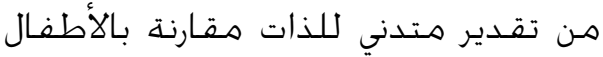

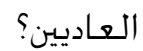
آ. ما فاعلية برنامج قائم على استراتيجية الذية

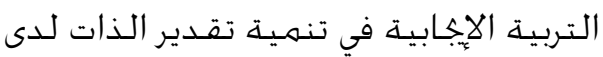

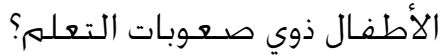

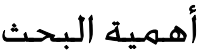

تنبع أهمية هذا البحث من أهمية تنمية ثقة

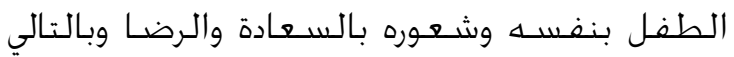

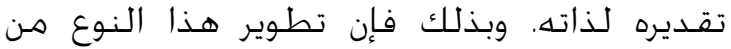

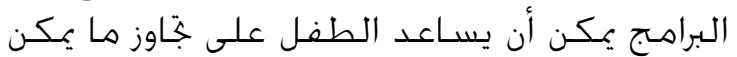

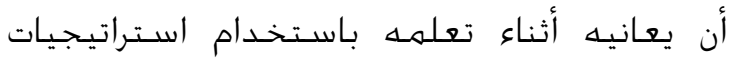

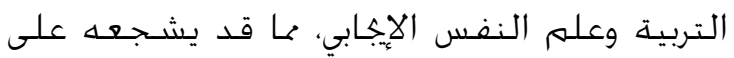

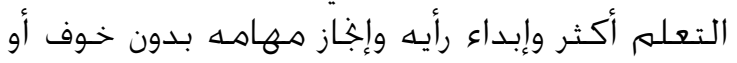

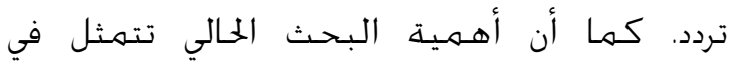

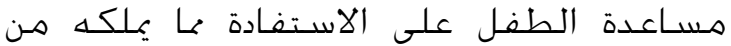


ويقتصــر البحتث الخالي على أطفـال المستـوى الثاني

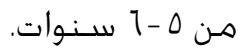

\section{الطريقة والإجراءات}

اعتمد البحث الحالي على المنهج شبه التجريبي

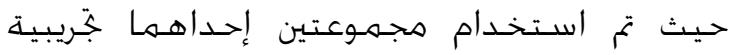

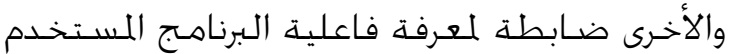

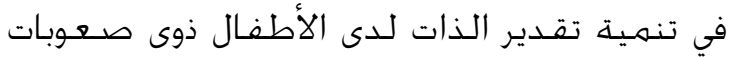

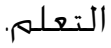

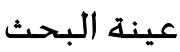

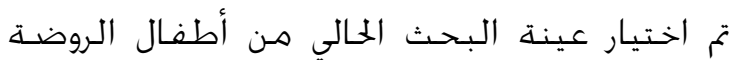

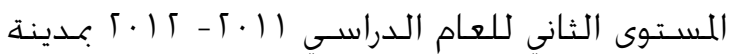

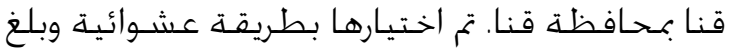

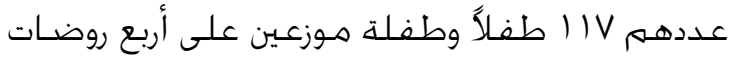
حكومية مختلفة. تم تطبيق بطارية اختبارات

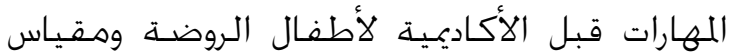

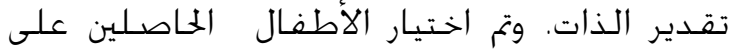
درجات أقل من ·0 على بطارية اختبارات المهارات الاتليات

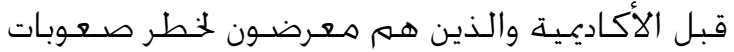

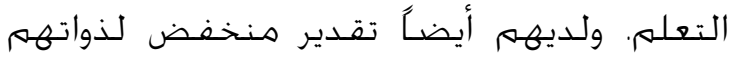

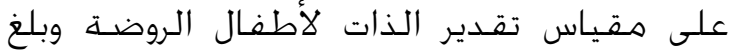
عددهم OV طفل وطفلة. تم تقسيم الأطفال بطريقة عشـوائية إلى مجهوعتين جُريبية بلغ عددها

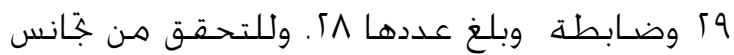

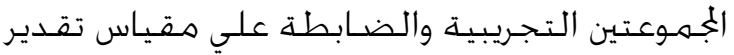

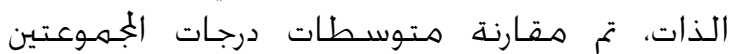

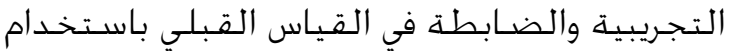

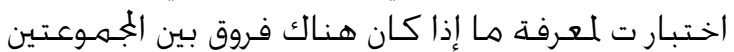
على مقياس تقدير الذات.

يتضح من جدول ( عدم وجود فروق دالة إحصـائيًً

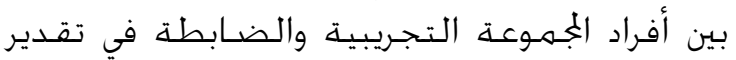

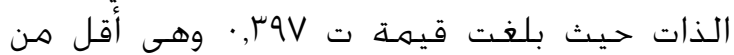

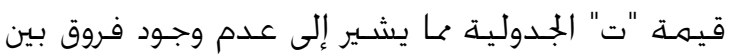

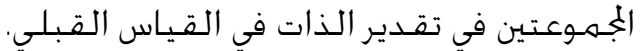

لصالح التطبيق البعدي عند مستوى

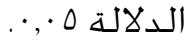

r. توجد فروق ذات دلالة احصائية بين

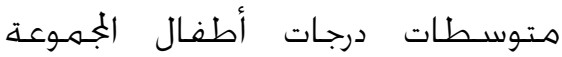
التجريبية ومتوسطات درجات أطفال الجمهوعة الضـابطة في التطبيق البعدي

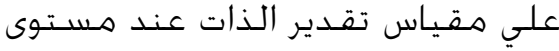

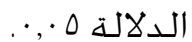

\section{مصطلحات البحث}

التربية الإيجابية: التعريف الإجرائي للتربية الإيجابية

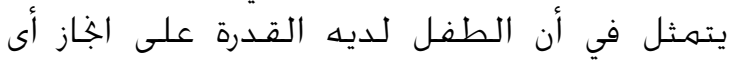

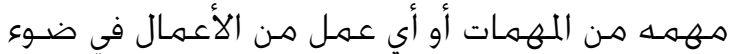

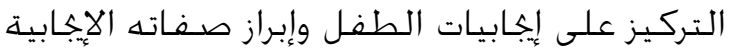

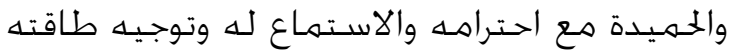

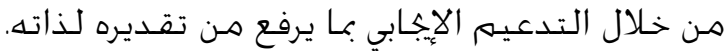

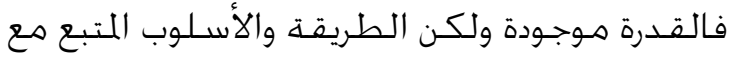
الطفـل هو الذي يسـاعد على توظيفهها أو كبتها.

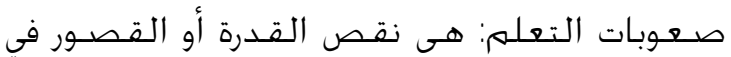

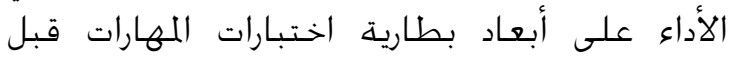

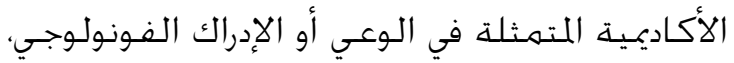

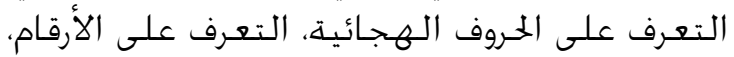

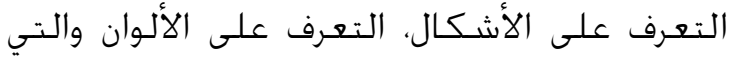

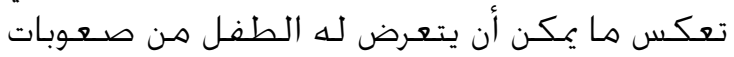

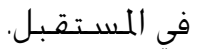

تقدير الذات: تقدير الذات هو احساس الطفل

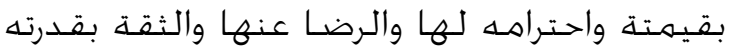

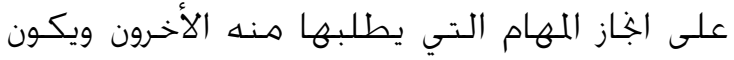

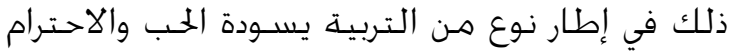

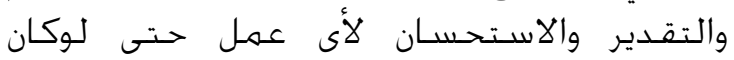

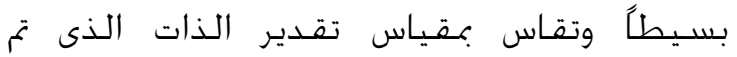
تصـيمهـ وإعداده لأطفال الروضـة.

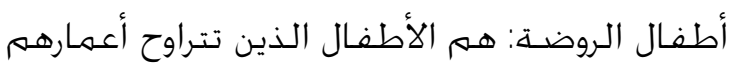

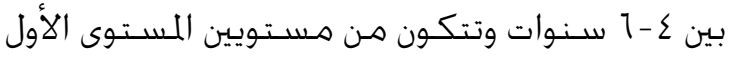

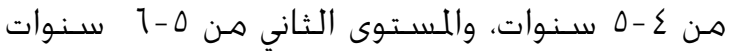

جدول العاين

قيمة ت لدلالة الفروق بين متوسطات درجات الأطفال العاديين والأطفال ذوي صعوبات التعلم على مفياس تفدير الذات

قبل تطبيق البرنامج الاهين

\begin{tabular}{|c|c|c|c|c|c|c|}
\hline الدلالة & قيـمـة ت & الاخراف اللعياري & المتوسـط & ن & التطبيق & الجسموعة \\
\hline غـير دال احصسائياً & $\cdot, \mu 9 \mathrm{~V}$ & T,Vq & $r \cdot, \cdot$ & $\Gamma \wedge$ & قبلي & الضـابطة \\
\hline & & $\Gamma, 1 \%$ & $r \cdot \Gamma \wedge$ & 19 & قبلي" & التجـريبيـة \\
\hline
\end{tabular}




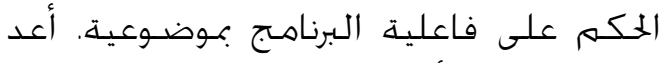

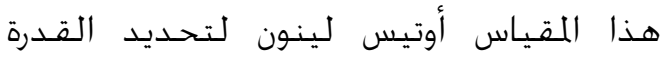

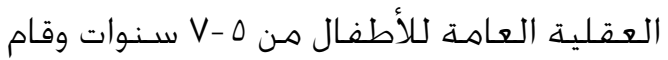

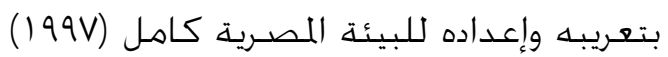

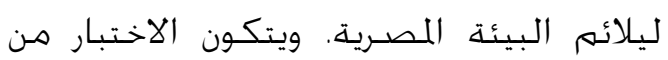

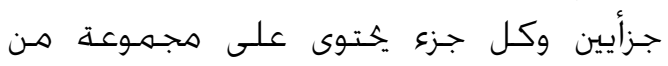

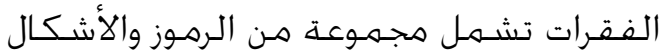

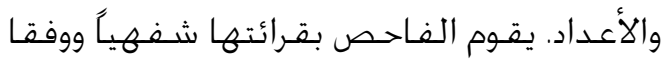

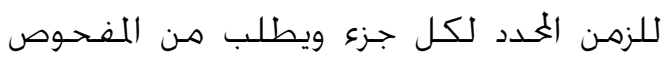

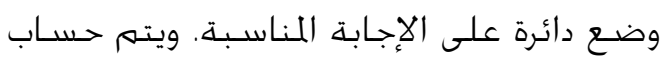

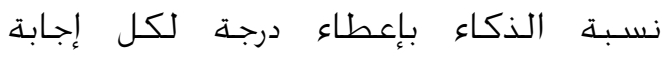

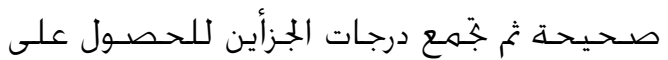

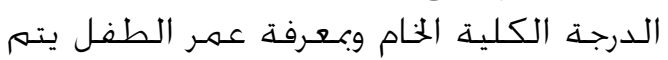

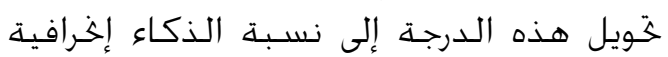

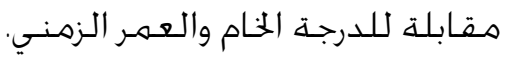
وتم حسـاب صـدق الاختبار عن طريق تقدير الإدير

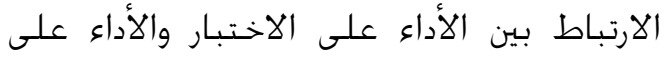
محكات تقيس نفس الوظائف لاختباري بينيه

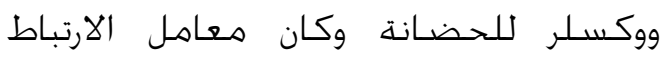
19V ، , oV

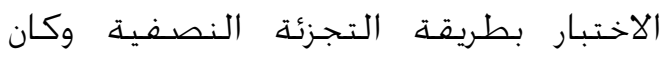

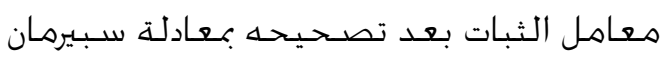

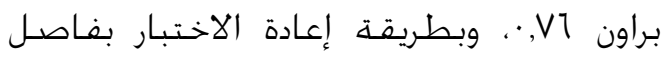

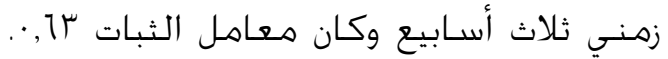

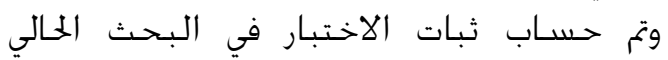

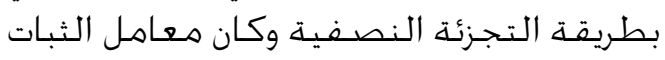

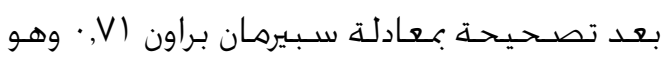
معامل ثبات مقبول.

ج. مفياس تقدير الذات لطفل ما قبل المدرسة:

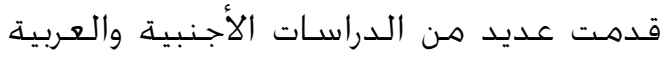

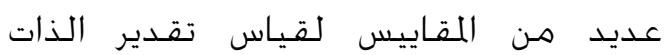

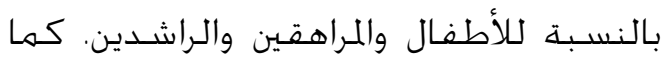
قامت بعض الدراسـات العربية بتعريب وتقنين واستـخــام بعض من هذه المقاييس في البئتين

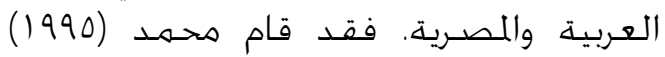

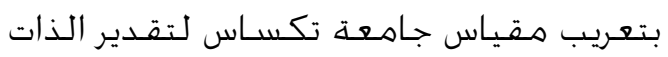

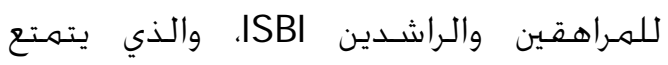

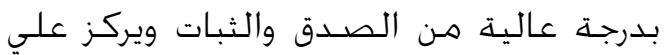

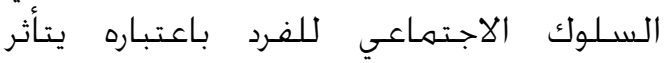
بتقديره لذاته. وفي هذا الاختبار، والاختبارات

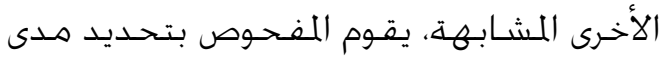

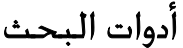

تم اسـتخـدام الأدوات الآتية لاجـراء البحـث:

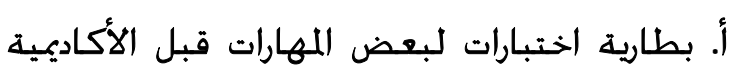

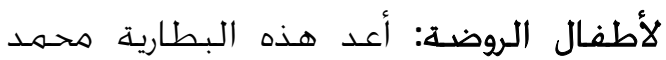

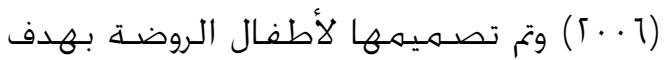
التعرف على قصـور المهارات قبل الأكاديمية.

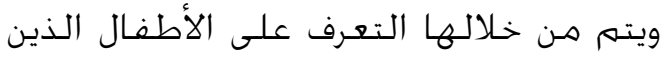

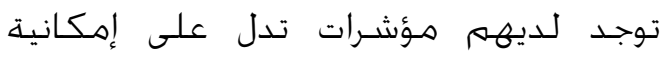

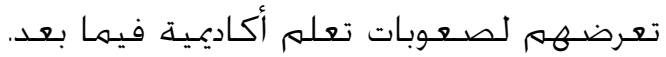
تتكون البطارية من خمس مقاييس فرعية

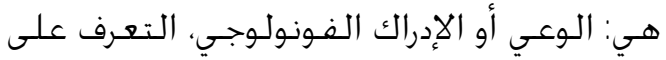
الحروف الهزجائية، التعرف على الأئرقام، التعرف التهرف

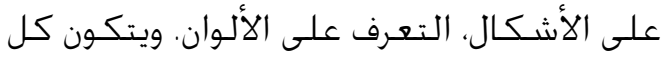

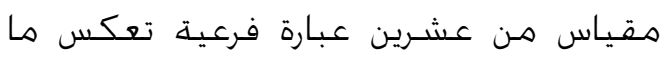

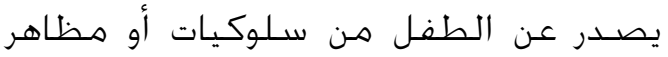

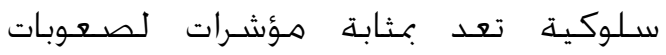

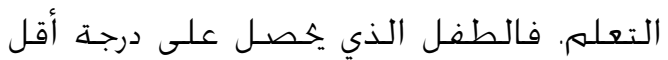

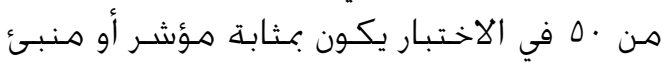

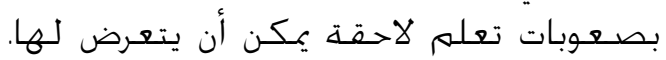

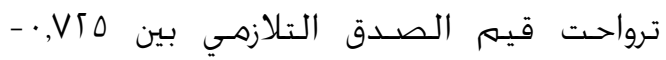

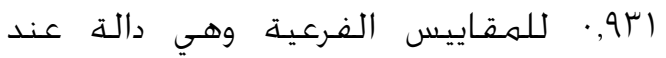

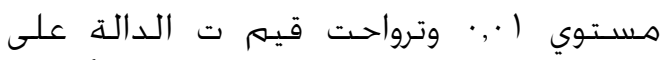

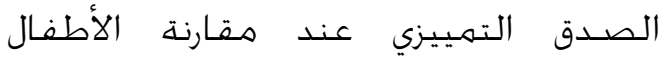

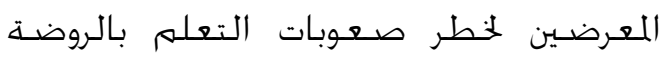

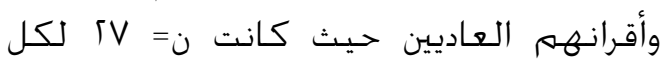

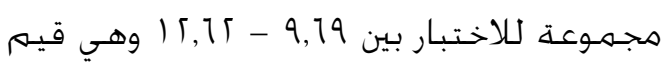

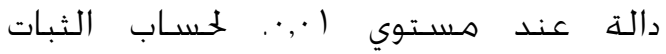

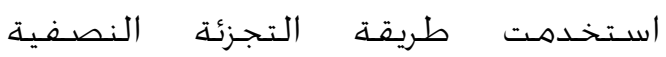

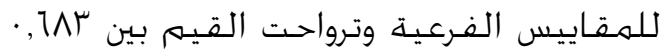

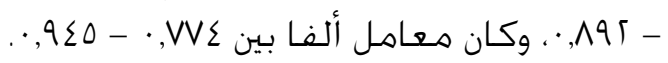

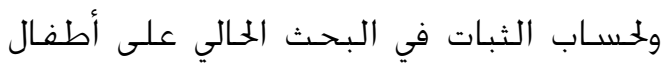

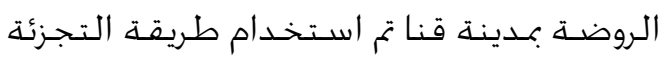

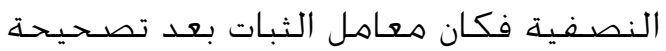

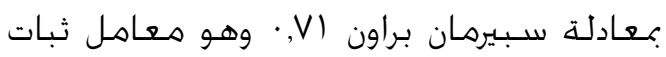

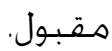

ب. اختبار القدرة العقلية العامة لـ أوتيس لينونه تم

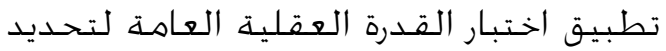

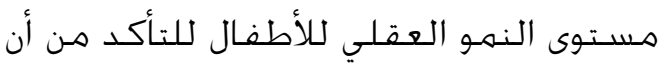

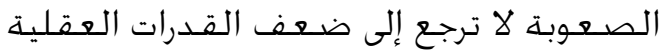

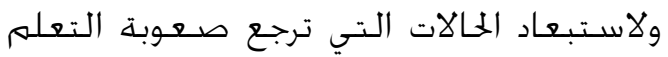

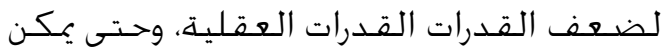




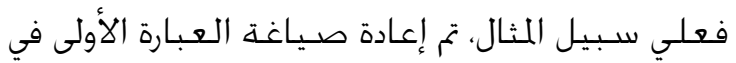

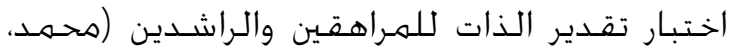

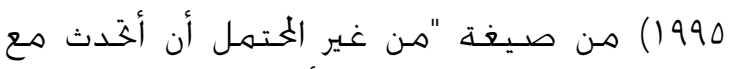

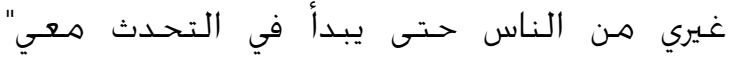

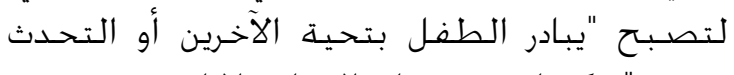

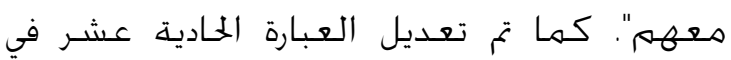

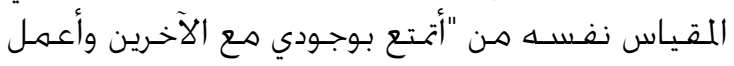

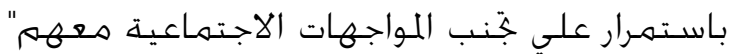

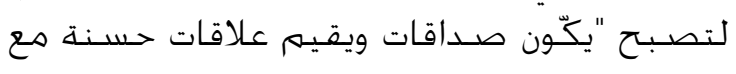

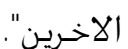

تكونت النسـخـة الأولية مـن المقياس مـ V ع عبارة.

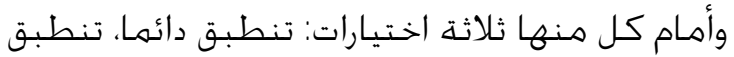

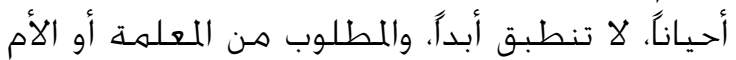

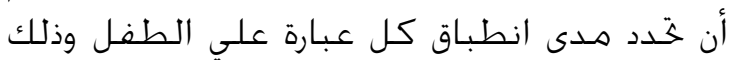

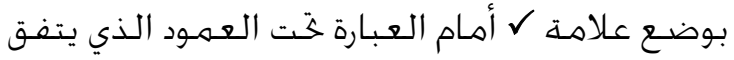

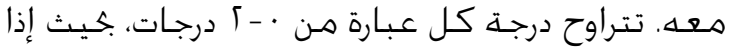

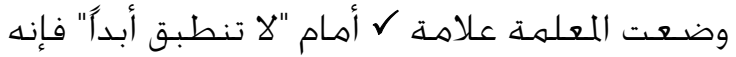

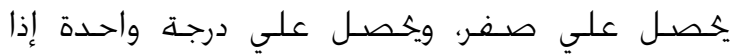

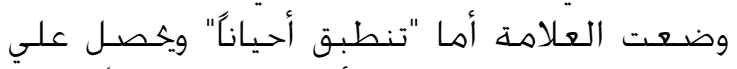
درجتين إذا وضعت العلامة أمام "تنطبق دائمهاً". ثبات المقياس: طبق المقياس علي عينة من الأطفال

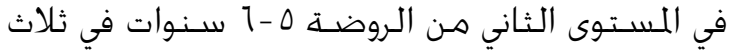

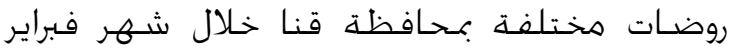

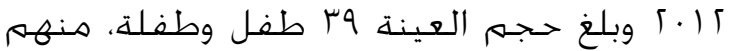

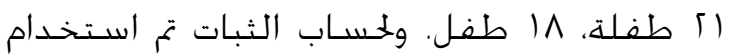

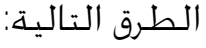

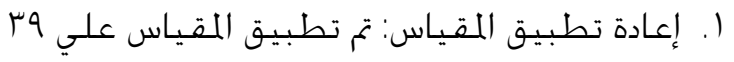

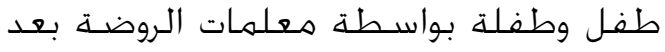
عقد عدة لقاءات معهم وتعريفهم بهرف الدراسـة وطبيعتها وكيفية تطبيق المقياس،

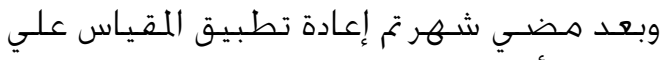

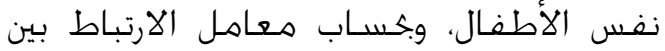

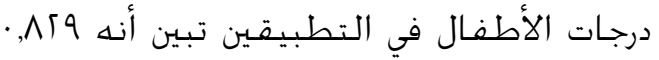
وهي قيمة دالة عند مسـتوى ال ال.,.

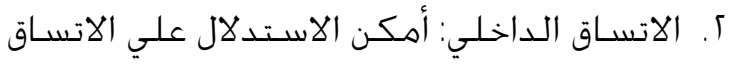

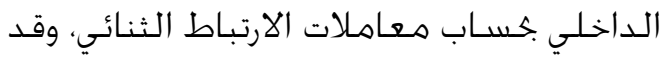

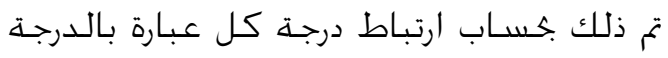
الكلية للمقياس. وقد تراوحت غالبية معاملات

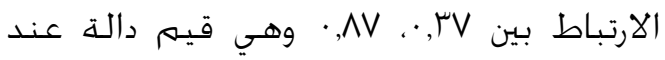

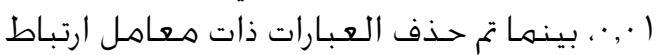

انطباق كل عباره عليه، حيث تتطلب الاجابة

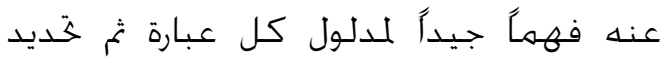

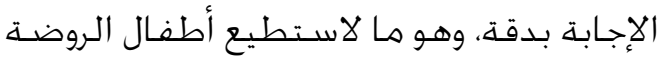

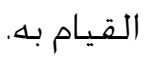

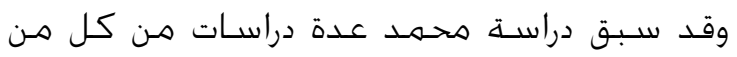

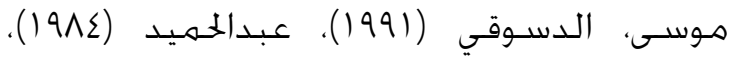

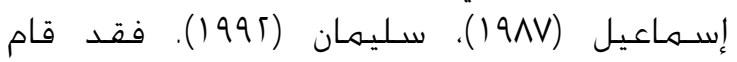

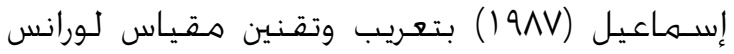

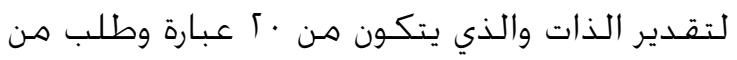

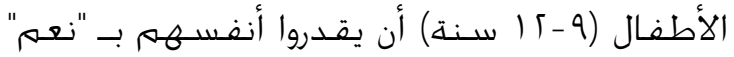

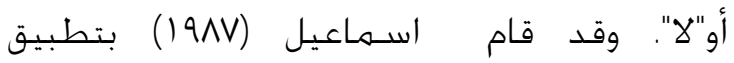

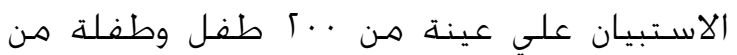

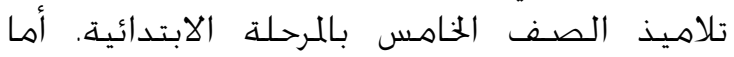

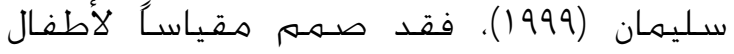

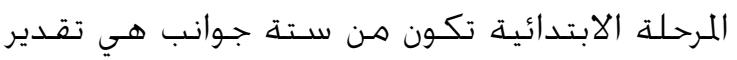

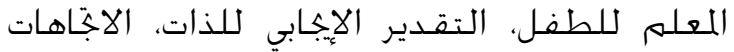

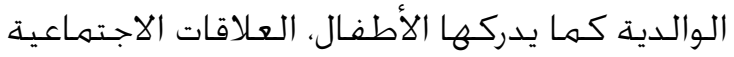

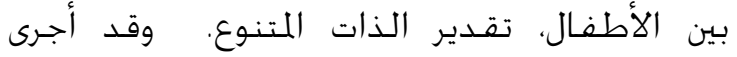

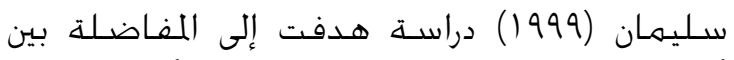

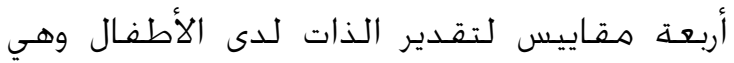

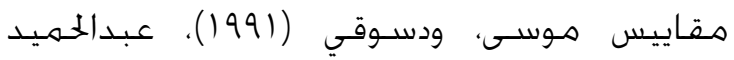

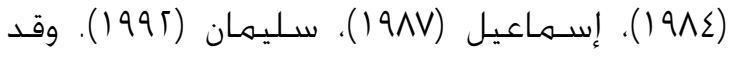

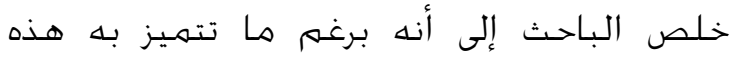

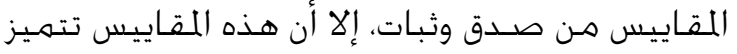

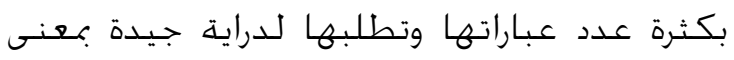

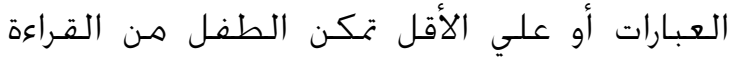

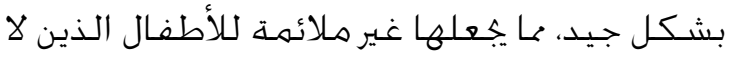

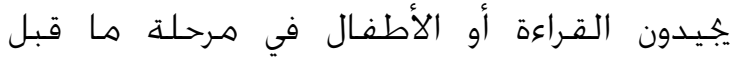
المدرسـة.

لذلك عمدت الدراســـة الحالية إلى إعادة إنتاج مقياس

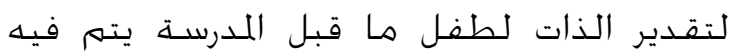

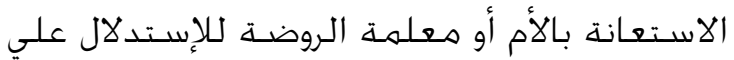

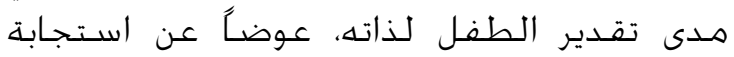

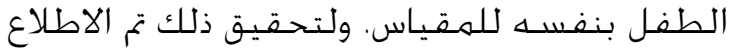

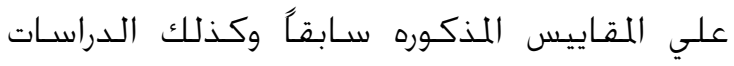

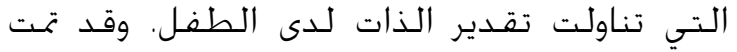

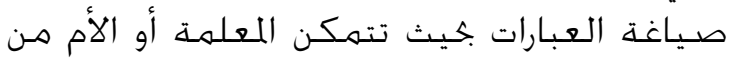

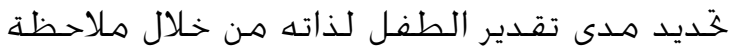

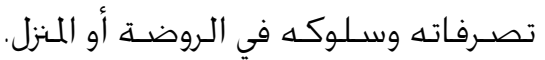




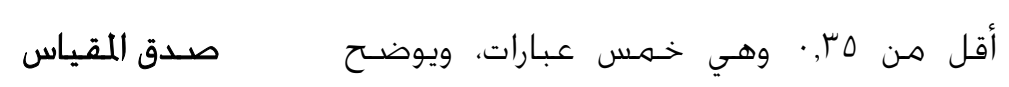

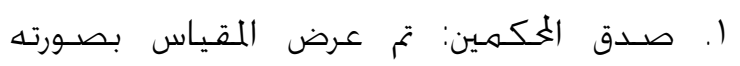

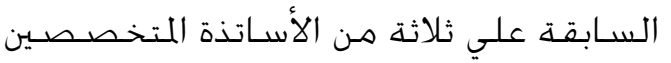

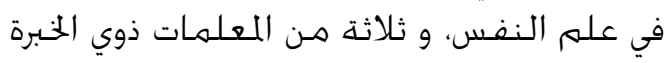

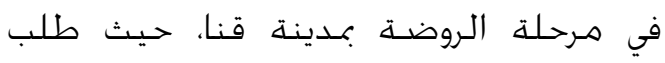
منهمه التحقق مـن وضـوح العبارات وانتمائها

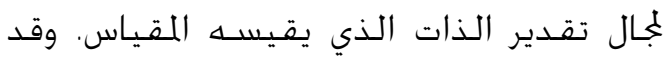

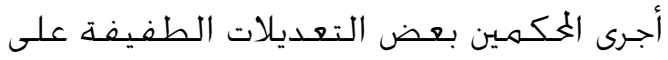
بعض عبارات المقياس، حيث بلغت الغيت نسبة الغية الاتفاق بين الخكمين ما بين V0 - V9\%.

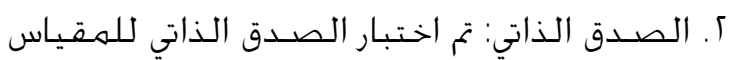

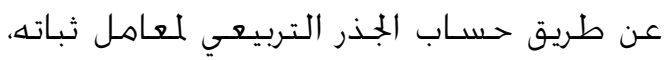

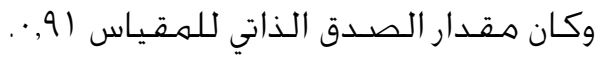

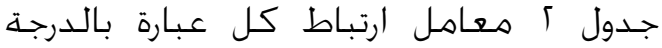
الكلية للمقياس، وبذلك أصبح عدل عدد عبارة عبارت المقياس ك广 عبارة.

وباسـتخدام طريقة التجزئة النصفية تم حسـاب

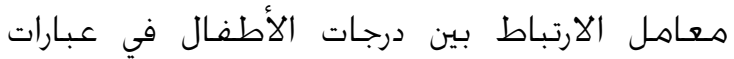

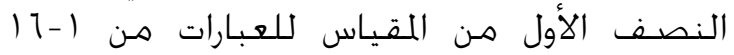

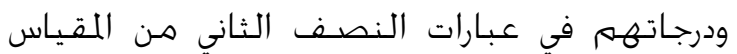

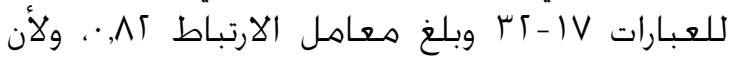

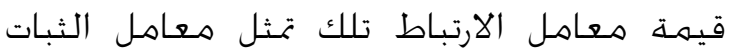

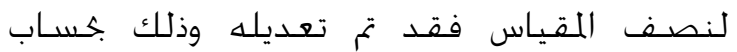

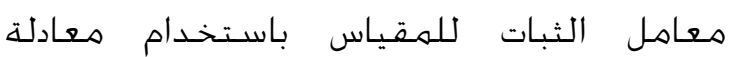
سبيرمان - براون وبذلك تكون قيمة معامل الثبات AV

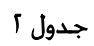

معاملات الارتباط بين الفقرة والدرجـ الكلية لعبارات مقياس تقدير الذات

\begin{tabular}{|c|c|}
\hline معامل الارتباط & 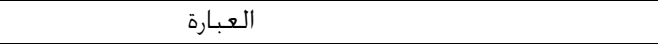 \\
\hline$\cdot, \mu \mathrm{V}$ & ا. يبادر الطفل بتحـية الآخـرين أو التحـدث معهمه. \\
\hline$\cdot, \sum 1$ & آ. عندما يسـقط الطفـل على الارض يحاول أن ينهض ويتهـاسـك. \\
\hline$\cdot, \Sigma 0$ & rا يـــــر بأنه مثل زملاؤه وليس أقل منهـم. \\
\hline$\cdot, \mu 4$ & ع. ينظف أو يرتب نفســ دون مسـاعدة. \\
\hline$\cdot, 01$ & 0. يتقبل نفسـه كمها هـ وسـعيد بنفسـه. \\
\hline$\cdot, 11$ & 1. لا يمل من اي جهـد لإثبات صـحـة وجهه نظرة \\
\hline$\cdot, \Sigma 9$ & 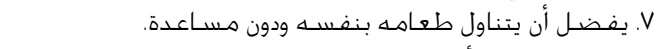 \\
\hline$\cdot, \wedge \vee$ & ^. يعبر عـن افكاره أو طلباته بشكل صـريح. . \\
\hline$\cdot, \mathrm{V} 1$ & 9. يعتز باسـمه ويقوله عندما يطلب منه. \\
\hline$\cdot, \wedge 9$ & • ا. يعتـر عند صـدور خطأ ما منـه. \\
\hline$\cdot, \Delta \Delta$ & 11. يحب الاختـلاط مع الأطفال الآخرين. \\
\hline$\cdot, \mathrm{VV}$ & 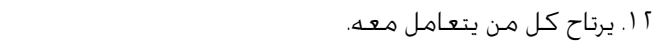 \\
\hline$\cdot, \sum 1$ & ب ا . يكـون صـداقات ويقيم علاقات حســــة مع الاخـرين. \\
\hline$\cdot, \Delta \Delta$ & 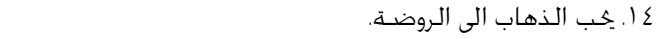 \\
\hline$\cdot, 10$ & ه ا. يحب مـارسـة الأنشـطـة الاجـماعية المختلفـة. \\
\hline$\cdot, \sum 1$ & 1 ا ا. لـديه القـدرة علي قيادة أقـرانه. \\
\hline$\cdot, \Sigma \Sigma$ & IV يعبر عن انفعالاته بشـكل متوازن بعيدا عن التوتر . \\
\hline$\cdot, 19$ & ^ا. يشـعر بأنه ذوقيمة وأن الأخرين يـتاجـون لمسـاعدته. \\
\hline$\cdot, 11$ & 9 1. يتقبل النقـد دون أن يؤثر على معنوياته. \\
\hline$\cdot, \mathrm{VV}$ & • آ. يعبر عن وجـه نظره بسـهولة ويسـر. \\
\hline$\cdot, \wedge)$ & آ. يتضـايق مـن ملاحظـات الأخرين. \\
\hline$\cdot, \sum 9$ & آ آ. يعتمدـ على نفسـه في حل ما قـد يواجهه مـن مشكلات. \\
\hline$\cdot, \Sigma 9$ & بآ. يتمتع بعلاقات جيدة مع الأخرين. \\
\hline$\cdot, r \wedge$ & ع آ. يعتمـد علي نفســ في الجاز مهامـه. \\
\hline$\cdot, \Sigma \Sigma$ & آ. يشـــر بأنــ مــميز عن الأخـرين \\
\hline$\cdot, 11$ & آ. يحترم الاخـرين. \\
\hline$\cdot, \mu q$ & IV يردد عبارات إيجابية مثل اســطيع أن أفعل ذلك. \\
\hline$\cdot, 11$ & ^ז. يسـاعد الأطفال الأخـرين. \\
\hline$\cdot, \wedge \wedge$ & 9 آ. يري أنه مستاز. \\
\hline$\cdot, \mathrm{VA}$ & • با. يري أنه سـيصـبح شخـصـا مهـما عندما يكبر. \\
\hline$\cdot, \mu q$ & ابّ. يسـتسـلم بسـهولة لأراء الأخرين. \\
\hline$\cdot, \Sigma 1$ & 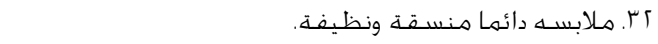 \\
\hline
\end{tabular}


لتطبيق اختبار التقدير الذاتي ثم خجميع

$$
\text { البيانات وخليل النتائج. }
$$

- استراتيجيات التربية الإيمابية المستخدمة في الميات

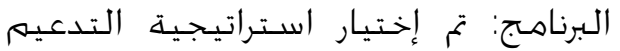

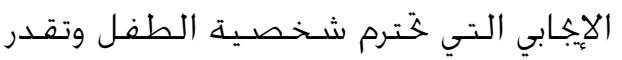
ما يقوم به الطفل من محاولات لالجاز

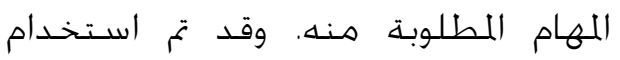

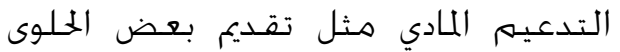

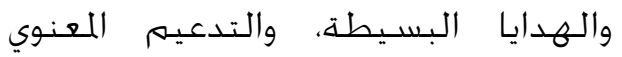

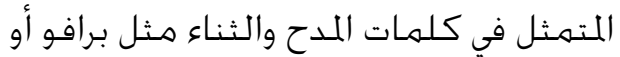

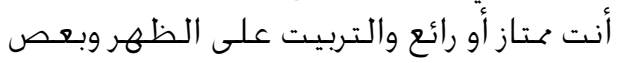

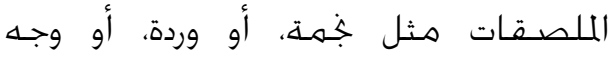

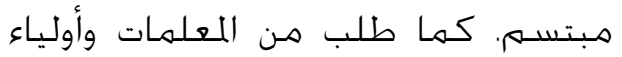
الأمور أثناء فترة تطبيق البرنامج تقبل ما لماء

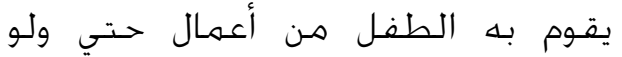
بسيطة واستـحسـان مايقوم به من أعمال.

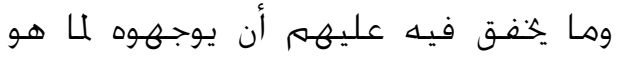
صـحيح مع ذكر عبارات ايجابية مثل "يمكنك انك

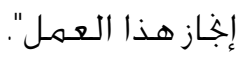

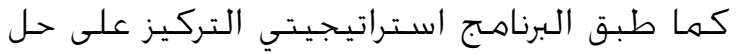

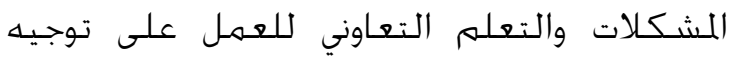

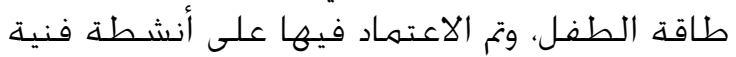

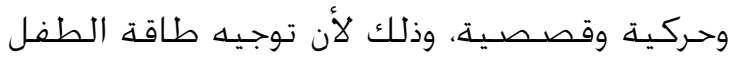

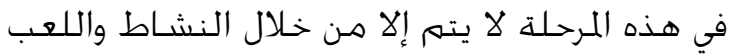

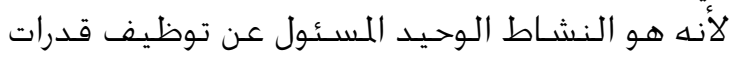
الطفل وإخراج ما لديه مـن قدرات وإمكانات (كمال.

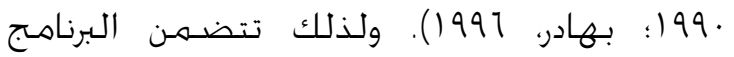

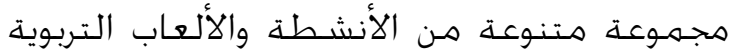

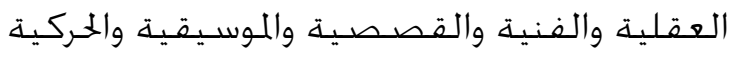

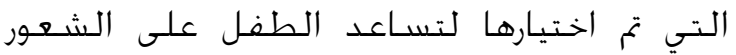

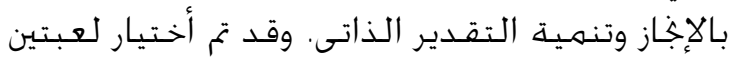

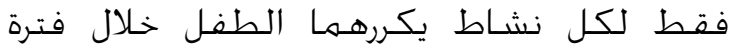

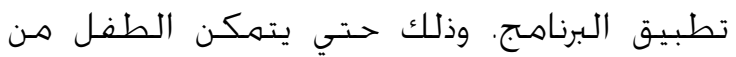

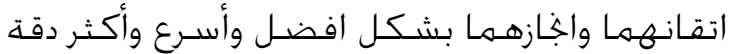

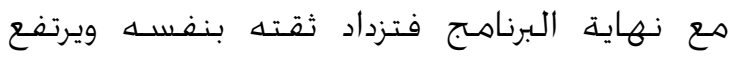
تقديره لذاته.

- أمثلة للأنشـطة المستخـدمة في جلسـات البرناهج:

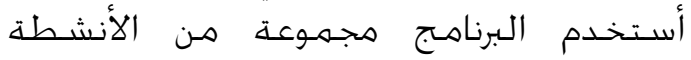

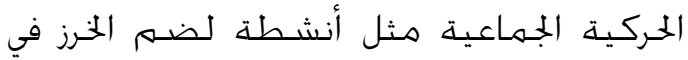

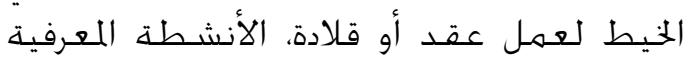

وتم حسـاب الدرجـة الكلية للمفـحوص في الاختبار

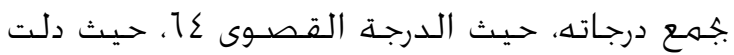

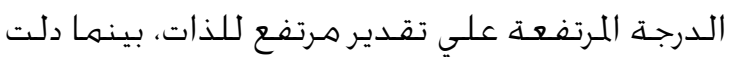

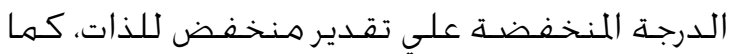

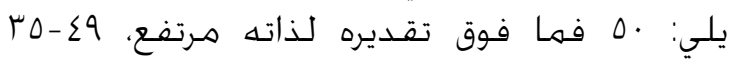

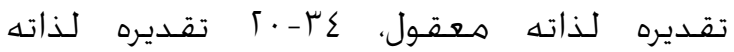

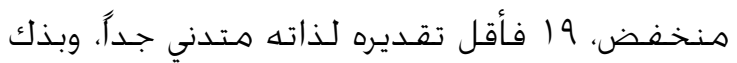

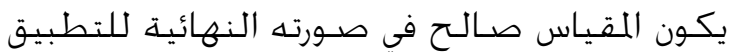
على الأطفال عينة الدراسـة.

\section{د. برنامج التربية الإيجابية للأطفال ذوي صعوبات}

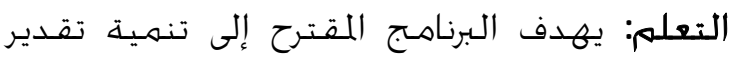

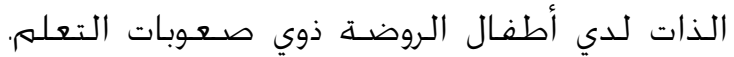

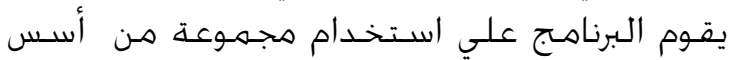
واستراتيجيات التربية الإيجابية.

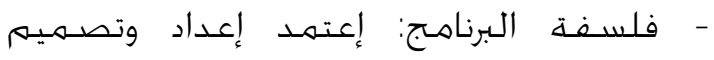

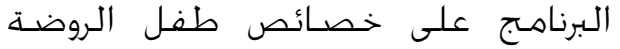

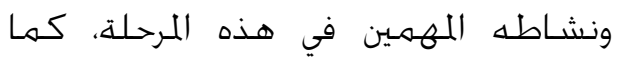

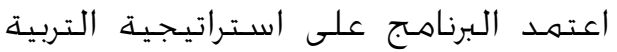
الإيجابية لتنمية التقدير الذاتي لتئية اللأطفال

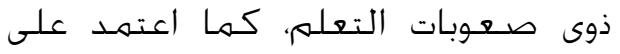
البحوث والدراسـات المتعلقة بتقدير الذات الذات التهات

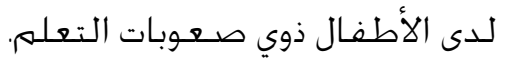
- محتوى البرنامج: تم خديد محتوى البرنامج بعد الإند

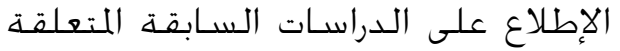

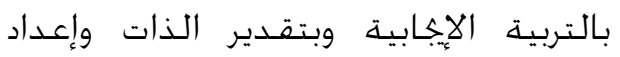

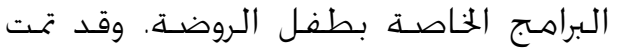

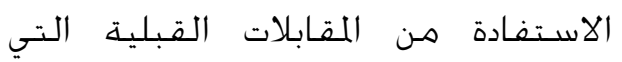
أجريت مع معلمات رياض الأطفال وأولياء

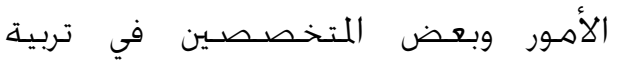

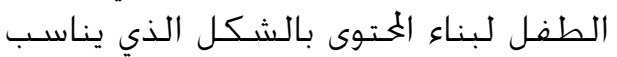

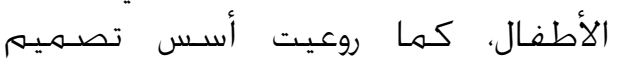

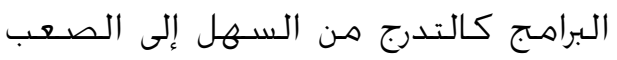

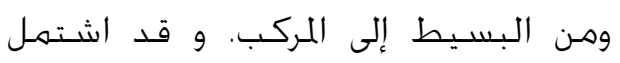

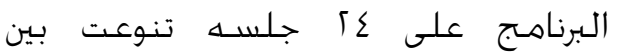

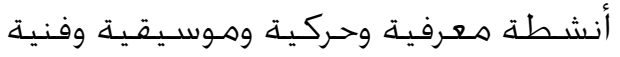

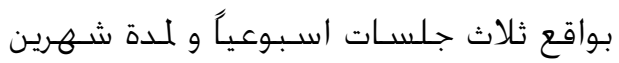

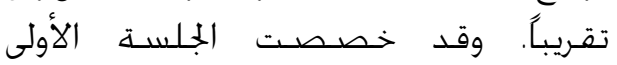
للتعارف وتوجيه الأطفال بأن لديهم العديد

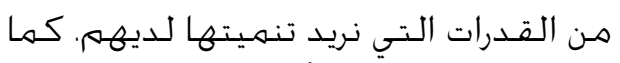

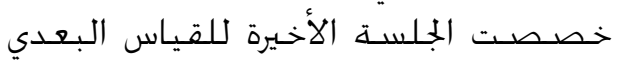


إيماءات القبول والاستحسـان لما يقوله الطفل.

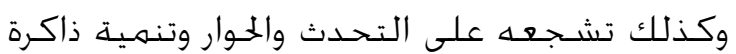

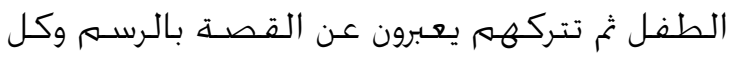

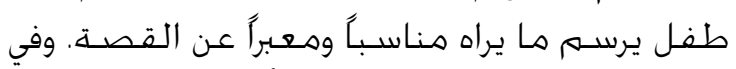

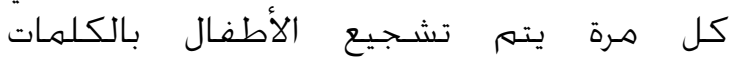

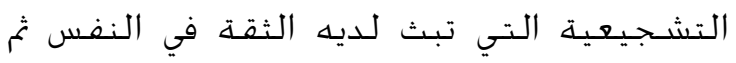

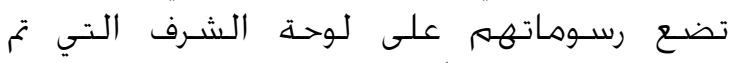

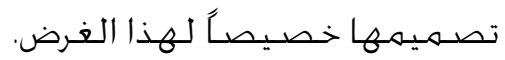

\section{النتائج والمناقشـة}

نتائج الفـرض الأول: "توجـد فروق ذات دلالة احسـائية

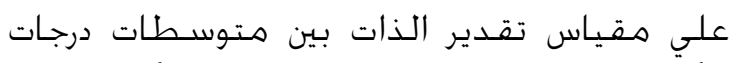

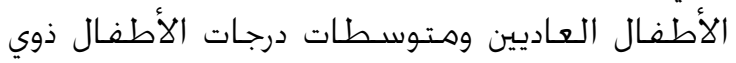

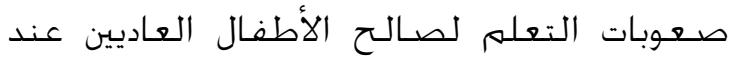

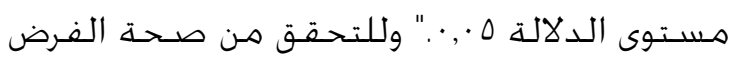
الأول تم تطبيق مقياس تقدير الذات علي الأطفال

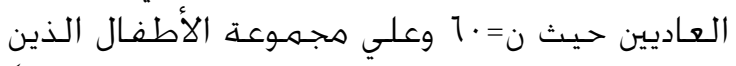

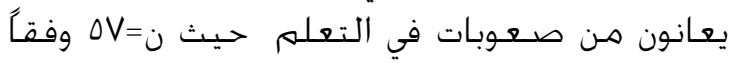
لنتائج بطارية اختبارات المهارات قبل فيل الأكاديمية لأطفـال الروضـة.

يتضح من جدول ب وجـود فروق دالة إحصـائيًاً بين

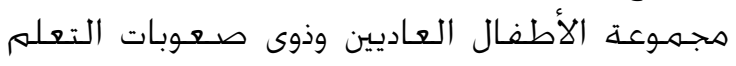

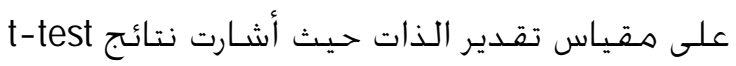

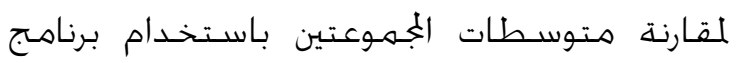
SPSS

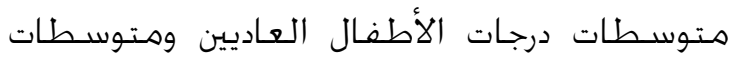

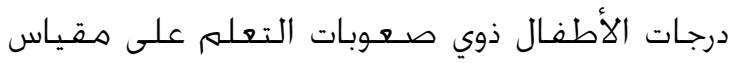

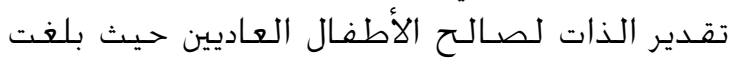

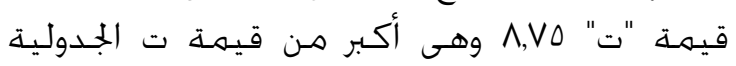

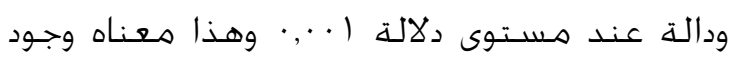
فروق بين الجمهـوعتين وهذه الفـروق لصالح العالح العاديين.

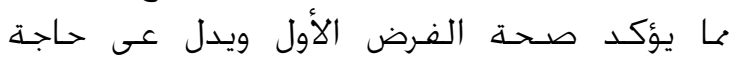
الأطفال ذوي صعوبات التعلم للبرنامهج التربية

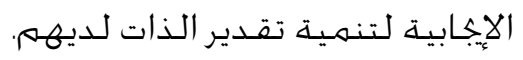

مثل نشاط تصنيف الأشكال الهندسية،

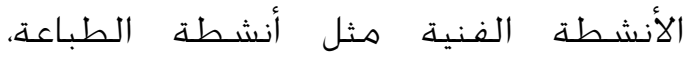

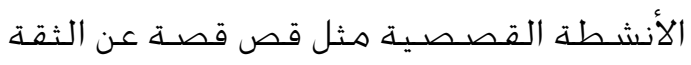

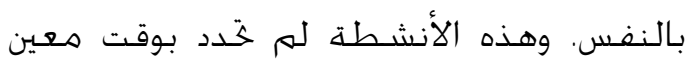

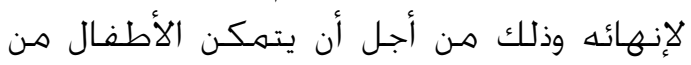

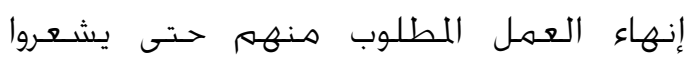

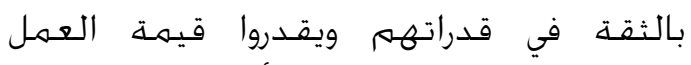

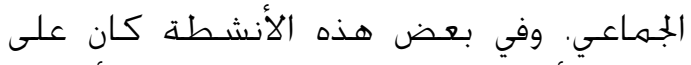

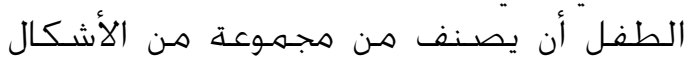

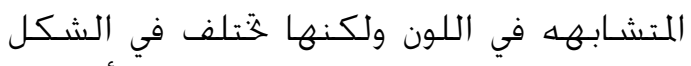

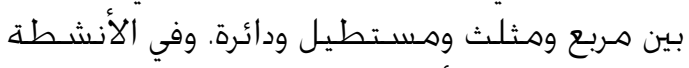

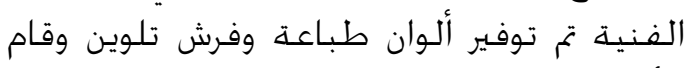

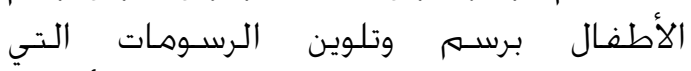
يفضلونها وفي كل رسـم يقوم بـه الأطفال

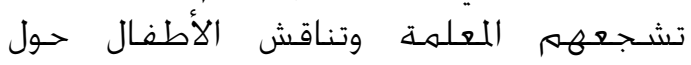

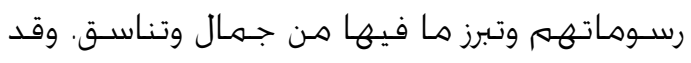

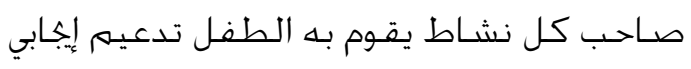
للطفل من مدح الطفل والثناء عليه

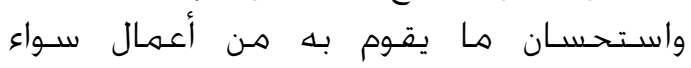
بالعبارات اللفظية الإيجابية أو الأشياء الحسية.

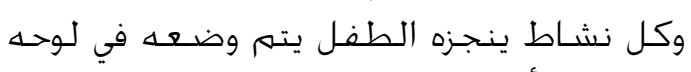

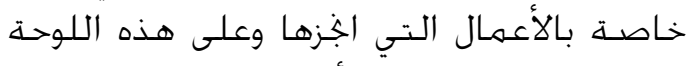

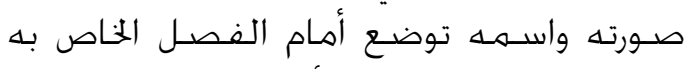

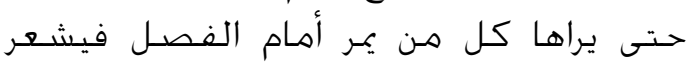

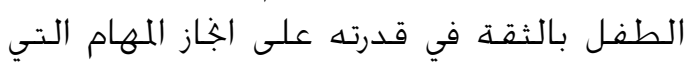

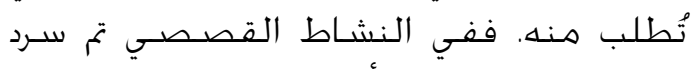

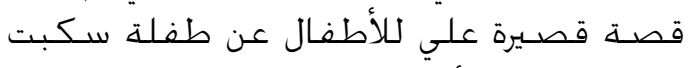

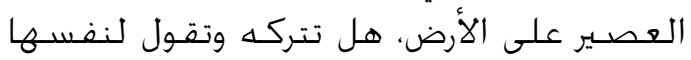

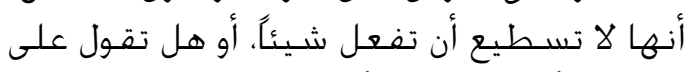

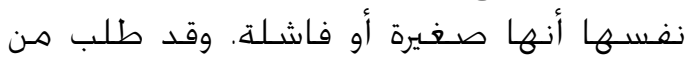

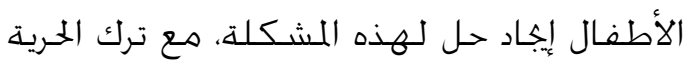

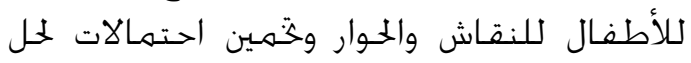
هذه الموقف.

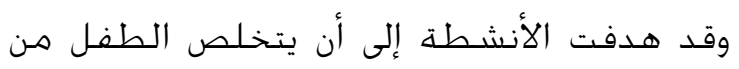

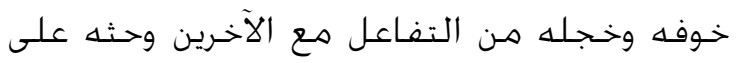

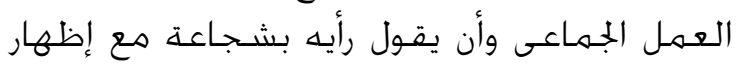

قيمة ت لدلالة الفروق بين متوسطات درجات الأطفال العاديين والأطفال ذوي صعوبات التعلم على

\begin{tabular}{|c|c|c|c|c|c|}
\hline \multicolumn{6}{|c|}{ مقياس تقدير الذات } \\
\hline مسـوى الدلالة & قيمة ت & الاخراف المعياري & المتوسط & ن & الجمهوعة \\
\hline$\cdot, \cdots 1$ & $\Lambda, \mathrm{VO}$ & $\Gamma, \Lambda \wedge$ & $r \Delta, \Sigma \mu^{\mu}$ & 7. & الضـابطة \\
\hline & & $\Gamma, 1 \wedge \vee \wedge$ & $r \cdot, 91$ & $\Delta V$ & التجريبية \\
\hline
\end{tabular}


يتضـح من جدول ه أنه توجد فروق ذات دلالة

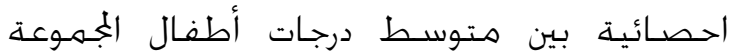

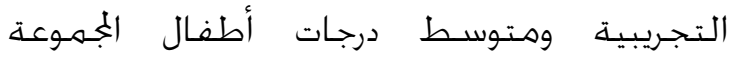
الضـابطة في التطبيق البعدي على مقياس تقدير

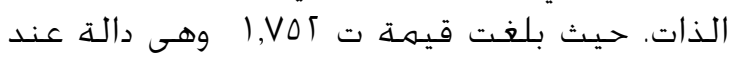

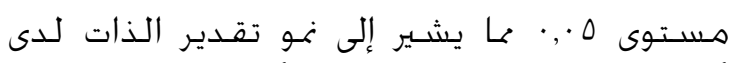

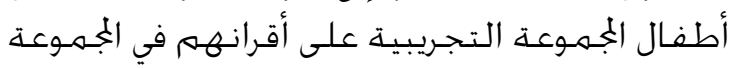

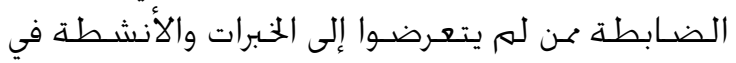
برنامج التربية الإيجابية، ويشير إلى فعالية البرنامهج. وتشـير النتائج السـابقة إلى فاعلية برنامـج التربية

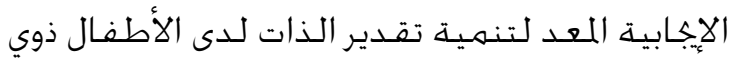
صعوبات التعلم، وذلك لأطفال الجمهوعة التجريبية.

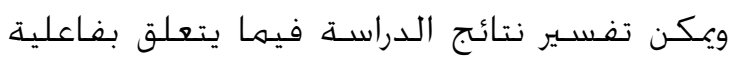

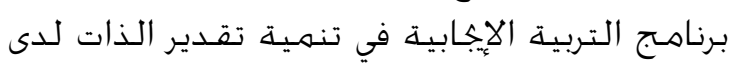

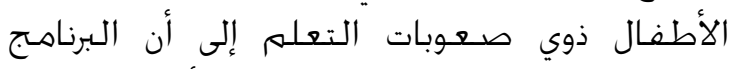

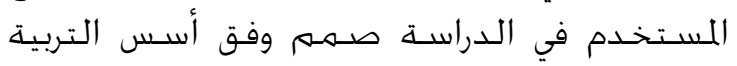

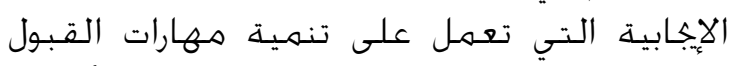

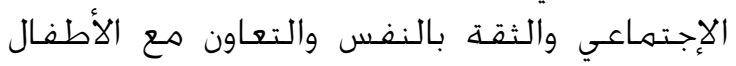

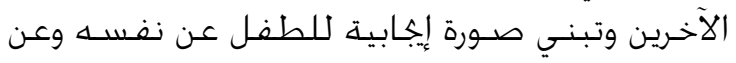

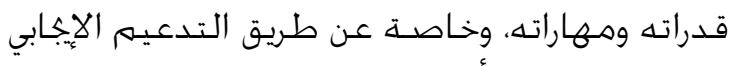

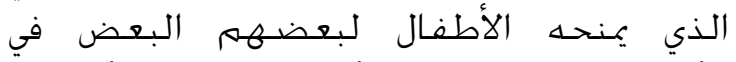

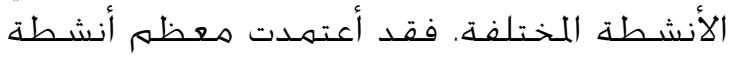
اسـتراتيجة التربية الإيجابية على تلدعيهم الرفاق. وأنشطة اللعب القـائم على التدعيم الإيجابي.

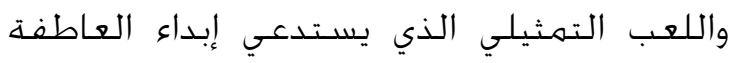

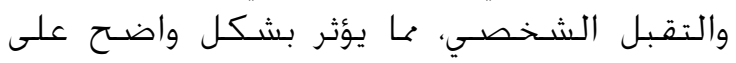

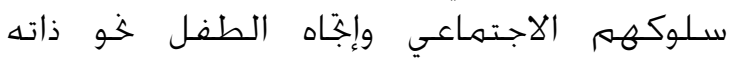

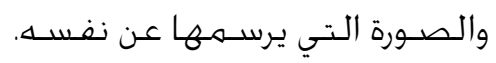

نتائج الفرض الثاني: "توجد فروق ذات دلالة احسـائية

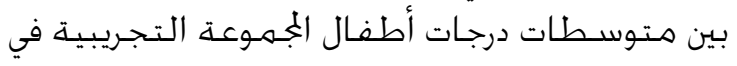

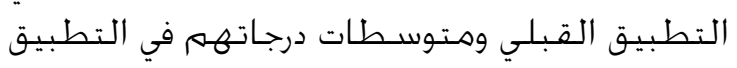

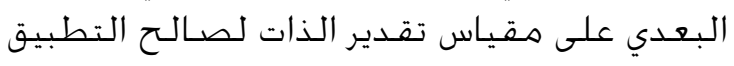

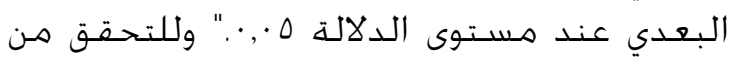

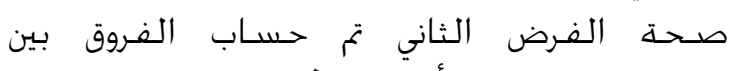

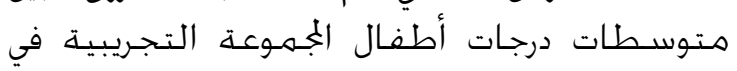

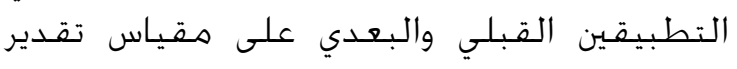

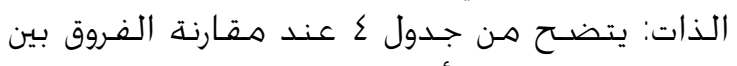

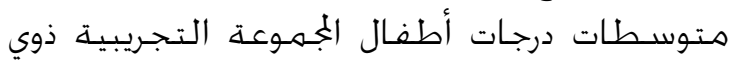

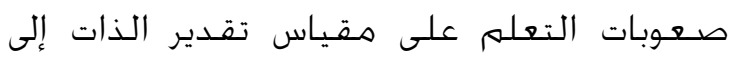

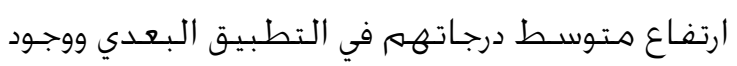

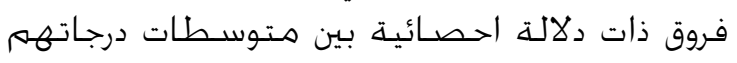

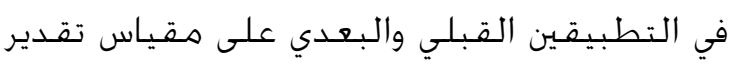

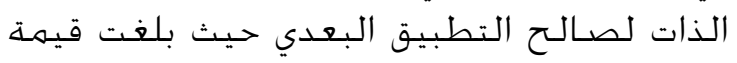

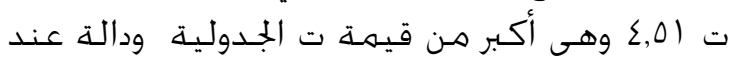

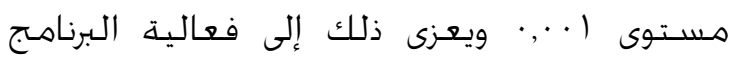

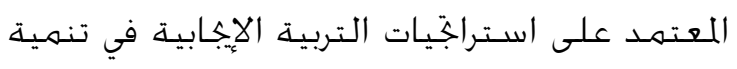

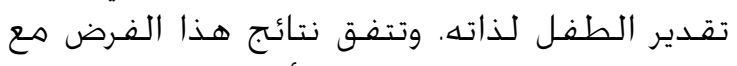

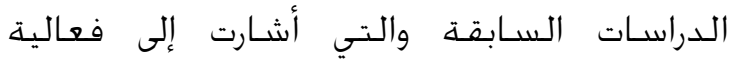

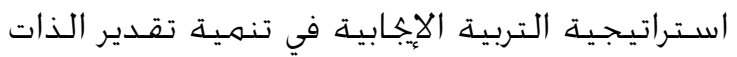
لدى الأطفال. نتائج الفرض الثالث: "توجد فروق ذات ذات دلالة

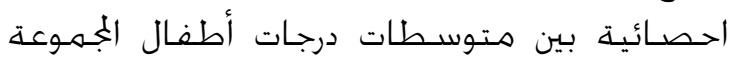

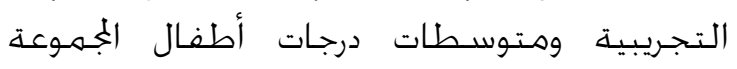

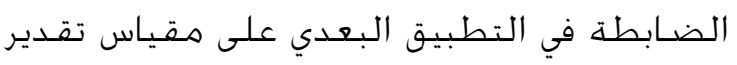

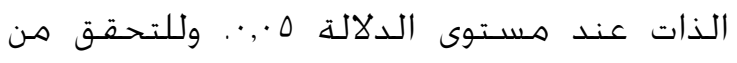

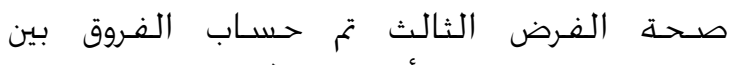

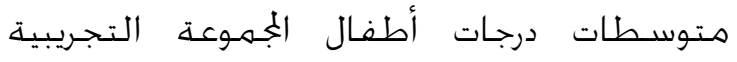

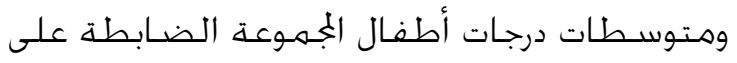
مقياس تقدير الذات

جدول

\begin{tabular}{|c|c|c|c|c|c|c|}
\hline \multicolumn{7}{|c|}{ تقدير الذات } \\
\hline مســوى الـلالة & قيمة ت & الاخراف المعياري & المتوسـط & ن & التطبيق & الجُمـوعة \\
\hline$\cdot, \cdot 1$ & $\left.\sum, 0\right)$ & $\Gamma, 7 \mu$ & $r \cdot r)$ & 19 & قبلي & التجريبية \\
\hline & & 1,71 & $r T, \wedge q$ & 19 & بعدي & التجريبية \\
\hline
\end{tabular}

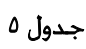

قيمة ت لدلالة الفروق بين منوسطات درجات أطفال الجمهوعة التجريبية ومتوسطات درجات أطفال الججموعة

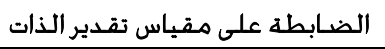

\begin{tabular}{|c|c|c|c|c|c|c|}
\hline مستـوى الدلالة & قيمة ت & الاخراف المعياري & المتوسـط & ن & التطبيق & الجلمهـوعة \\
\hline$\cdot, \cdot 0$ & I,VOT & $\Gamma, 1 \varepsilon$ & $r \cdot r)$ & $\Gamma \Lambda$ & بعدي & الضـابطة \\
\hline & & $\Gamma, 7 \mu$ & $r, 0 \mu$ & 19 & بعدي & التجريبية \\
\hline
\end{tabular}




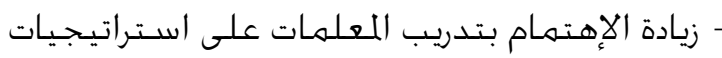

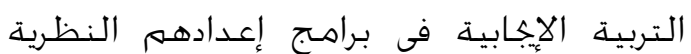
والتطبيقية، وكذلك تقديم الدورات التدريبية التراهية

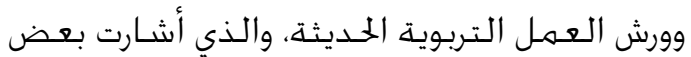

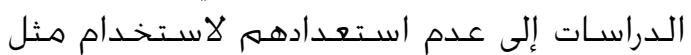

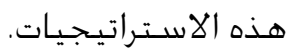

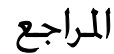

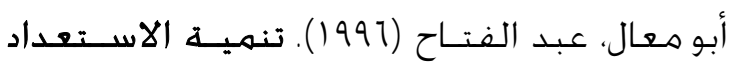
اللغوى عند الأطفال. عمان: دار الشـروق.

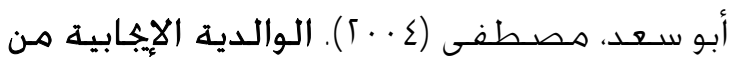

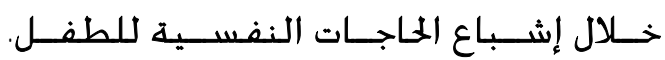
الكويت: مكتبة الكويت الوطنية.

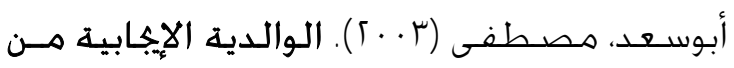

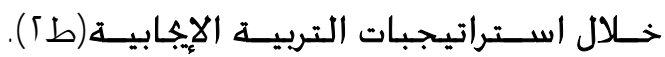
الكويت: مكتبة المنار الإسـلامية.

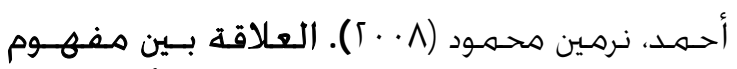

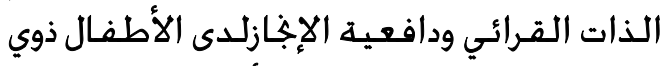

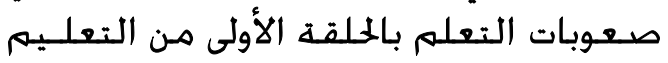

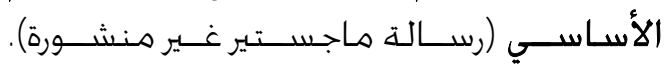
معهد دراسـات الطفولة - جامعة عين شـمسي. جمهورية مصر العربية.

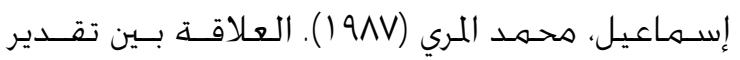

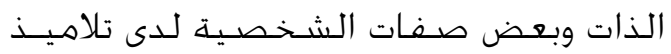
المرحلة الابتدائية. مجلة كلية التربية -جامعة تلامة لامدات

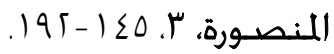

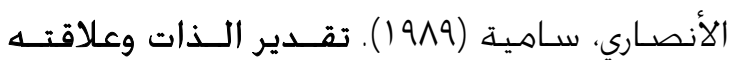

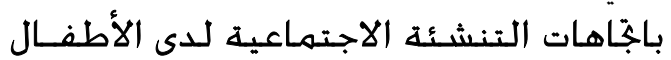

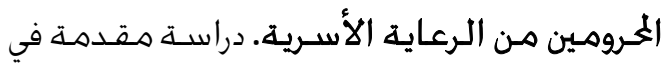

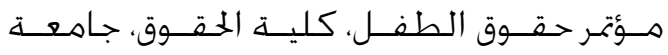

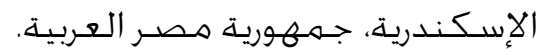

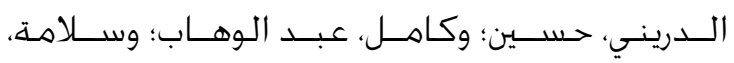

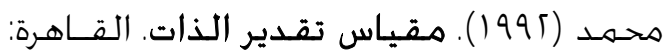

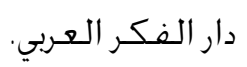

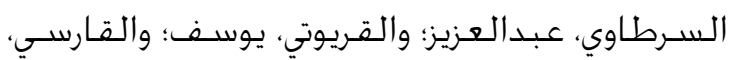

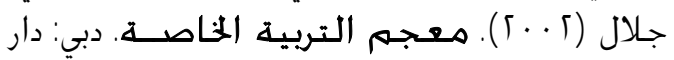

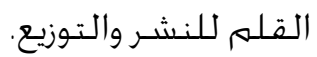

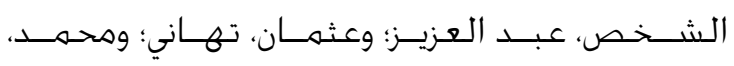

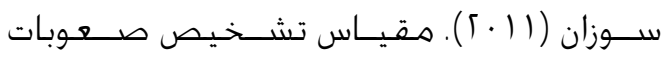

وتظهر النتائج أيضًاً أنه بالرغم من بساطة

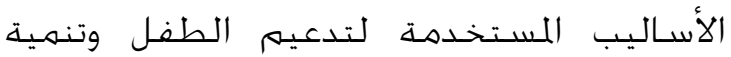

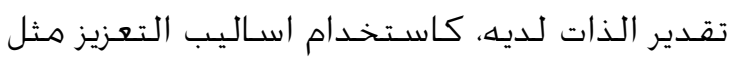

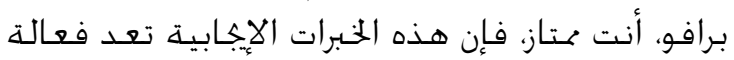

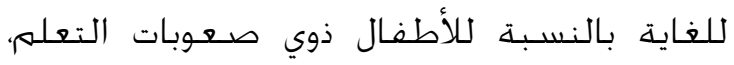
ليس فقط لتدعيم السـلوك أو لتعليم مهارات

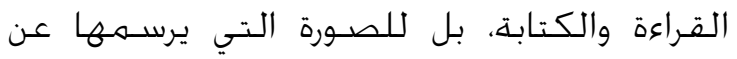

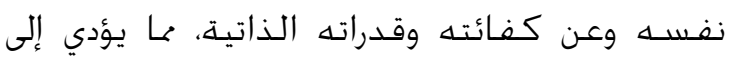

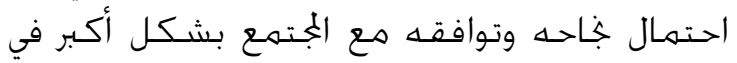

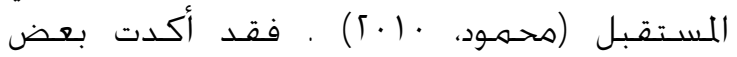

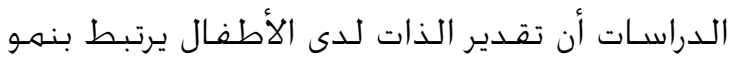

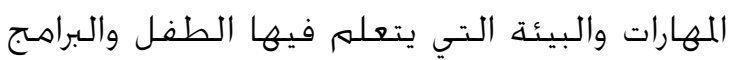

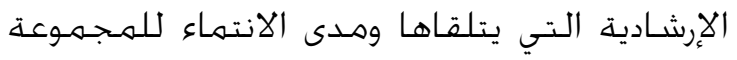

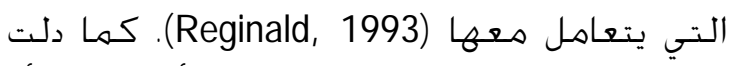

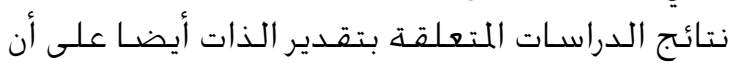

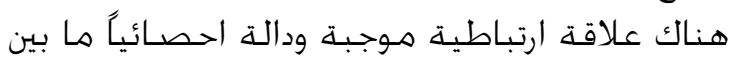
تقدير الذات والإجذاز الأكاديمي. وبذلك فإن نتائج البحثث الحالي تؤكد على ضـرورة الاهتمام بتخطيط برامج التربية الإيجابية للأطفال.

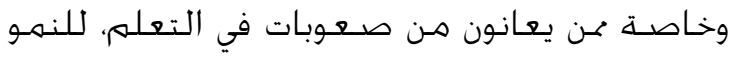

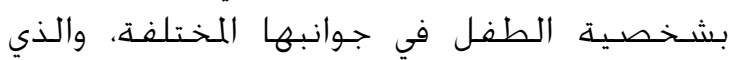

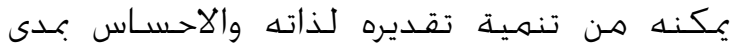

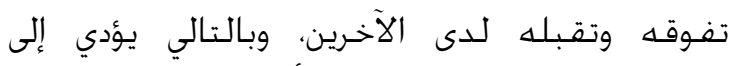

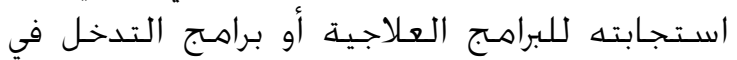

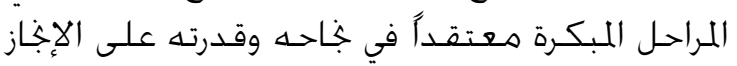

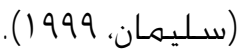

التوصيات

جتمل الدراسـة الحالية توصياتها في النقاط التالية: - العمل على تطبيق استراتيجية التربية الإيجايبية

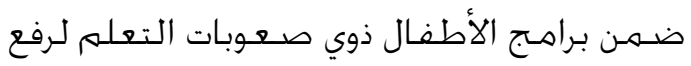

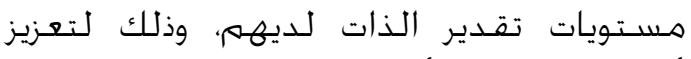

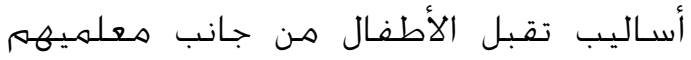

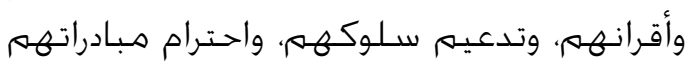
وحريتهمه في التعبير. وتدعز - إجراء مزيد من البحـوث حول العلاقة بين أسـاليب

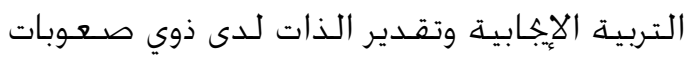

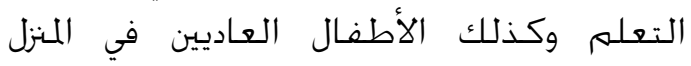

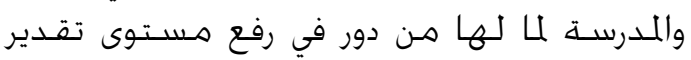

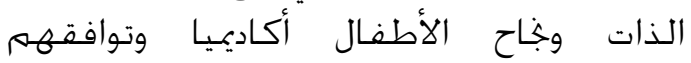

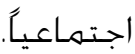


بقطر: دراسـة سيكومترية. مجلة علم النفس،

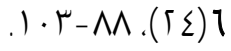

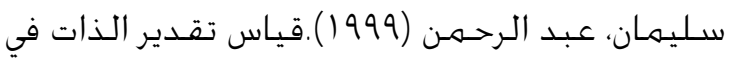

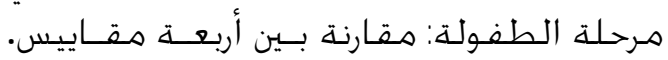

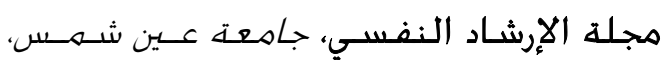
.1 $\mu-\Lambda V .11$

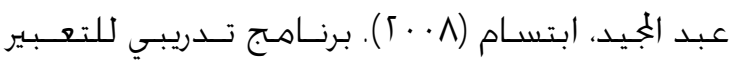

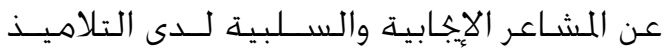

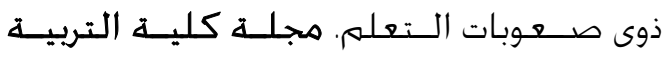

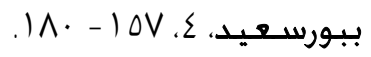

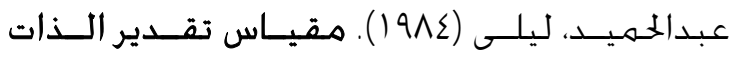

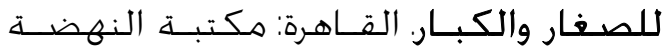
المصـرية.

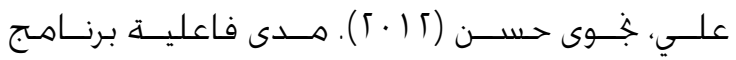

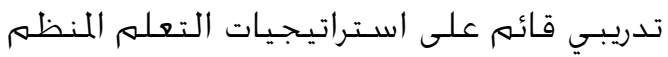

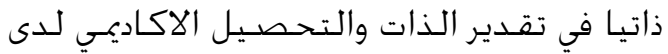

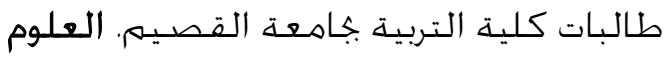

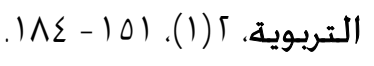

كامل، مصطفي (99V) (1). اختبار القــدرة العقليـة العامة. القاهرة: مكتبة الأجلو المصـرية.

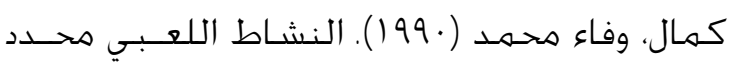

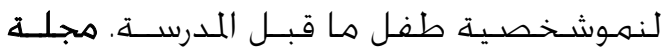

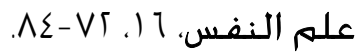

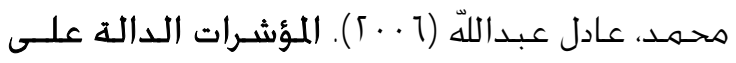

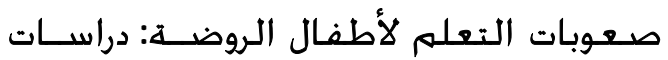
تطبيقية، القـاهرة: دار الرشـاد.

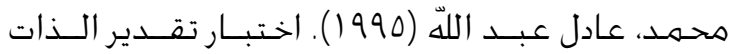

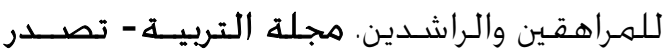

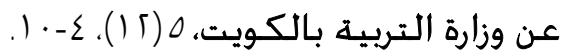
محمدد، عادل عبدالله ( (999) اختبـار تقــدير الــذات

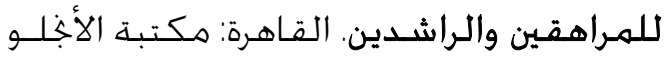
المصرية.

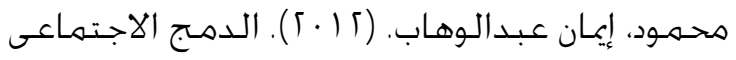

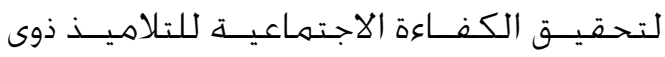

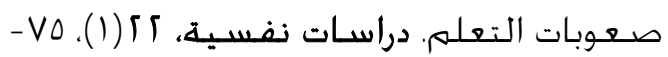
$.1 \cdot r$

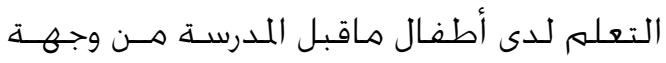

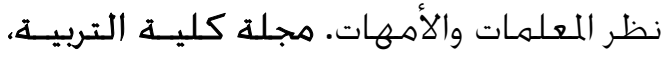

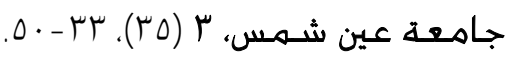

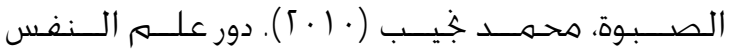

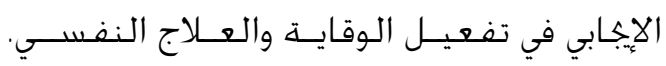
دراسـات عربية في علم النفس، 9 (1)، ( - 0).

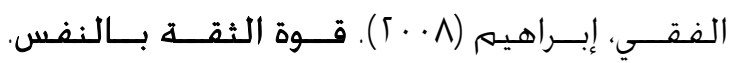
القـاهرة:دار اليقين للنشـر والتوزيع.

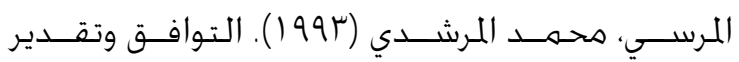

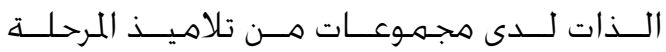

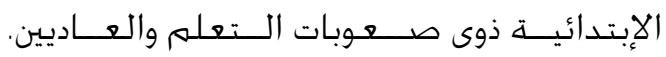
مجلة كلية التربية، جامعة عين شـمس، ع(ع () ) $.119-101$

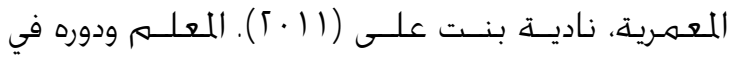

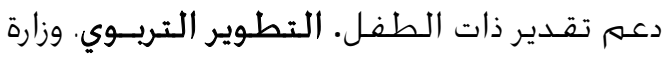

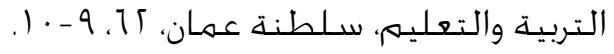

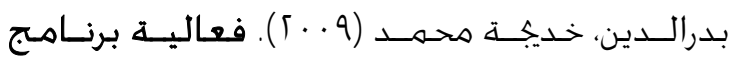

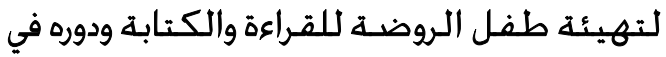
التغلب على بعض صعوبات التعلم (رسـالة

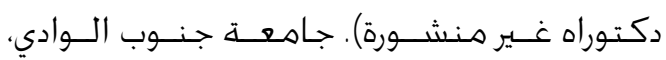
جمهورية مصر العربية. بدير، كريــان ( ( . ). التعليم المستقبلي للأطفال.

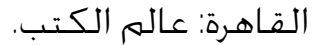

بهادر، سـدية محـمد (997 ()). المرجع في برامج تربية

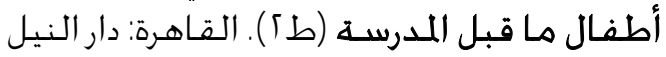
للطباعة والنشر.

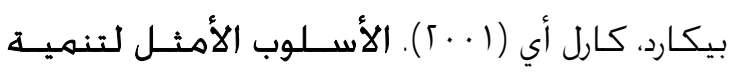

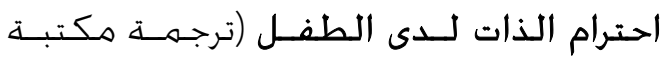
جرير).الرياض: مكتبة جـرير.

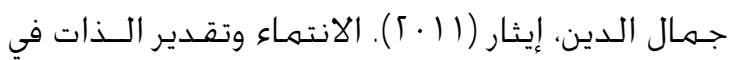

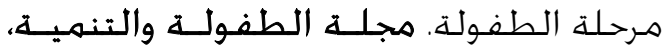

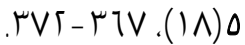

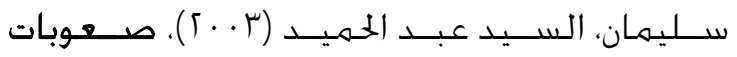

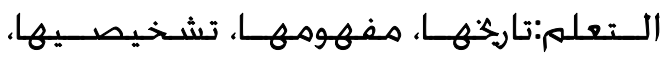

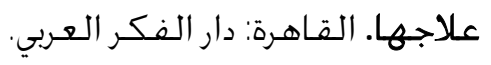

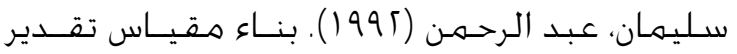

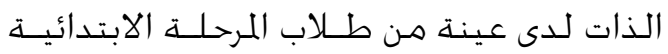


Criss, M., Pettit, S., Bates, E., Dodge, K. A., \& Lapp, A.L. (2002). Family adversity, positive peer relationships, and children's externalizing behavior: A longitudinal perspective on risk and resilience. Child D evelopment, 73, 1220-1237.

Martin P., Randal M., Jane, G., Karen, R., \& Mark, L.(2009). Positive education: positive psychology and classroom interventions. Oxford Review of Education, 35(3), 293-311.

Noble T., \& McGrath, H. (2007). The positive educational practices framework: Leadership transforming schools through optimism. Paper presented at the ACEL/ASCD Conference: N ew Imagery for Schools and Schooling: Challenging, Creating, and Connecting, Sydney, Australia, 10-12 October.

Nobel, T., \& M cGrath, H. (2008). The positive educational practices framework: A tool for facilitating the work of educational psychologists in promoting pupil well being.Educational and Child Psychology, 25(2), 119-134.

Reginald, S. (1993). Predictors of depression in street children.Journal of A dolescence, 28(109), 41-53.

Seligman, M. (2002). Positive psychology, positive prevention, and positive therapy. In Snyder, C. \& Lopez, S. (Eds.). The $\mathrm{H}$ andbook of Positive Psychology (pp. 3-9). New York: Oxford University Press.

Seligmana, M., Ernstb, R., Gillhamc, J., Reivicha, K., \& Linkinsd, M. (2009). Positive education: positive psychology and classroom interventions. Oxford Review of Education, 35(3), 293-311.

$$
\begin{aligned}
& \text { محمود، ماجــدة حسـيـن (· ( • ). السـلوك العـدواني }
\end{aligned}
$$

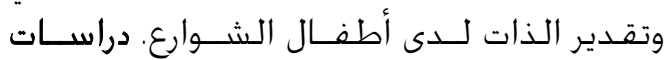

$$
\begin{aligned}
& \text {.) } \Sigma \varepsilon-\Sigma 9 .(1) \Gamma \text {. }
\end{aligned}
$$

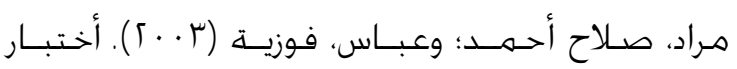

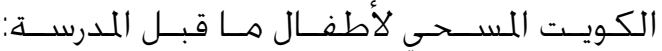

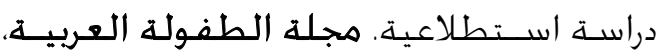

$$
\begin{aligned}
& \text {.ro- } 9.1 \varepsilon
\end{aligned}
$$

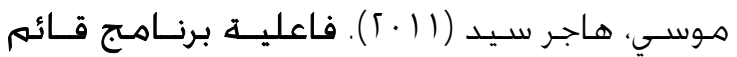

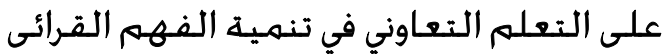

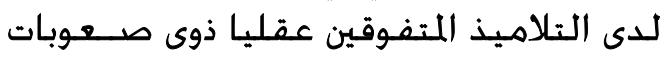

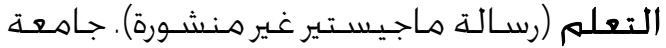

$$
\begin{aligned}
& \text { المنصـورة، جهمهورية مصـر العربية. }
\end{aligned}
$$

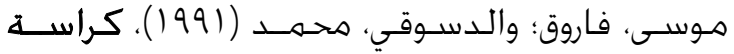

$$
\begin{aligned}
& \text { تعليمات اختبار تقدير الذات للأطفــال (طع). }
\end{aligned}
$$

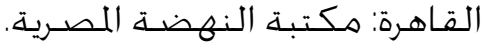

$$
\begin{aligned}
& \text { هنلي، مارتن؛ ورامزى، روبرتا، وألجــوزين، روبـرت ( ( . ؟). }
\end{aligned}
$$

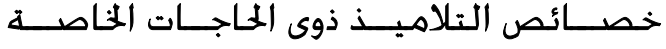

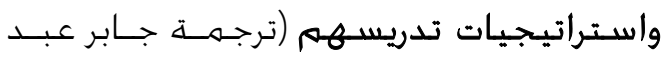

$$
\begin{aligned}
& \text { الحـميد جابر). القـاهرة: دار الفكر العربي. }
\end{aligned}
$$

